University of Louisville

ThinkIR: The University of Louisville's Institutional Repository

Electronic Theses and Dissertations

$12-2020$

\title{
The corporate venture dyad: a study of the impact of cultural distance on venture performance.
}

Tommie R. Welcher

University of Louisville

Follow this and additional works at: https://ir.library.louisville.edu/etd

Part of the Entrepreneurial and Small Business Operations Commons, and the International Business Commons

\section{Recommended Citation}

Welcher, Tommie R., "The corporate venture dyad: a study of the impact of cultural distance on venture performance." (2020). Electronic Theses and Dissertations. Paper 3565.

https://doi.org/10.18297/etd/3565

This Doctoral Dissertation is brought to you for free and open access by ThinkIR: The University of Louisville's Institutional Repository. It has been accepted for inclusion in Electronic Theses and Dissertations by an authorized administrator of ThinkIR: The University of Louisville's Institutional Repository. This title appears here courtesy of the author, who has retained all other copyrights. For more information, please contact thinkir@louisville.edu. 
THE CORPORATE VENTURE DYAD: A STUDY OF THE IMPACT OF CULTURAL DISTANCE ON VENTURE PERFORMANCE

\author{
By \\ Tommie R. Welcher \\ B.A., University of Louisville, 2009 \\ M.B.A., University of Louisville, 2015

\begin{abstract}
A Dissertation
Submitted to the Faculty of the College of Business of the University of Louisville in partial Fulfillment of the Requirements

for the degree of
\end{abstract}

Doctor of Philosophy in Entrepreneurship

\author{
Entrepreneurship Department \\ College of Business \\ University of Louisville \\ Louisville, KY
}

December 2020 
Copyright 2020 by Tommie R. Welcher

All rights reserved 

THE CORPORATE VENTURE DYAD: A STUDY OF THE IMPACT OF CULTURAL DISTANCE ON VENTURE PERFORMANCE

\section{By}

Tommie R. Welcher

B.A., University of Louisville, 2009

M.B.A., University of Louisville, 2015

A Dissertation Approved on

October 15, 2020

by the following Dissertation Committee:

Robert P. Garrett

James O. Fiet

Simon Parker

David Dubofsky 


\section{DEDICATION}

This dissertation is dedicated to my family including my dad and mom Lennie and Karen and my wife Sheila 


\section{ACKNOWLEDGEMENTS}

I would like to thank my wife for her patience, support, and understanding as I worked through the completion of a very difficult process. I would also like to thank my parents for their support and patience as I have work through this process. The support and love of my family has made the completion of this process possible.

I would like to thank my dissertation chair, Dr. Robert Garrett, for his patience and guidance through this process. I would also like to thank my other committee members for their assistance and comments; Dr. Fiet, Dr. Parker, and Dr. Dubofsky.

I would also like to thank Dr. Minola for his valuable contribution of helping us to collect data from Italian corporations. I want to thank Dr. Aguirre Aguirre for his valuable contributions of helping to collect data from Mexican corporations. Also, I would like to thank Vernon Foster for his help in making introductions with businesses in the Louisville area that assisted with data collection locally. 


\section{ABSTRACT \\ THE CORPORATE VENTURE DYAD: A STUDY OF THE IMPACT OF CULTURAL DISTANCE ON VENTURE PERFORMANCE}

Tommie R. Welcher

October 15,2020

Even though corporate ventures (CVs) provide many benefits to established corporations, they continue to fail at a high rate. Whereas research supports that a corporation can gain a parenting advantage over its competitors (Campbell et al., 1995), there is no evidence to support that starting more CVs leads to more successful CVs. Parenting advantage theory postulates that if a corporation with a parenting advantage starts a venture then that venture will be more successful than if any of their competitors had started the same venture (Campbell et al., 1995). CVs are typified by dynamism and innovation, but established corporations have a duty to maximize shareholder returns while minimizing risks (Simon et al., 1999). The divergence of these two cultures can create cultural friction at the interface of the interacting corporate and venture managers. I analyzed these relationships to understand what impact cultural distance could have on $\mathrm{CV}$ performance. I found that an increase in corporate cultural distance is associated with a decrease in venture success. My findings suggest that even though a corporation may possess resources that could benefit its venture, that cultural distance between a parent and its venture could be inhibiting the transfer of these resources to its venture leading to lower levels of venture success. 


\section{TABLE OF CONTENTS}

\section{Page}

Acknowledgments iv

Abstract

$\mathrm{v}$

List of Figures

vii

List of Tables

viii

Chapter I: Introduction $\quad 1$

Chapter II: Literature Review and Hypothesis Development 13

Chapter III: Methods

Chapter IV: Results $\quad 48$

$\begin{array}{ll}\text { Chapter V: Discussion } & 58\end{array}$

$\begin{array}{ll}\text { References } & 65\end{array}$

$\begin{array}{ll}\text { Appendix } & 76\end{array}$

$\begin{array}{ll}\text { Curriculum Vita } & 95\end{array}$ 


\section{LIST OF FIGURES}

Figure

1. Research Model

2. New Business Identification Matrix
Page

9

38 


\section{LIST OF TABLES}

\section{Table}

Page

1. Companies Identified per Country

2. Companies that Participated per Country

36

3. Descriptive Statistics

49

4. Correlation Matrix

50

5. Results of HLM using CDCM

51

6. Results of HLM using CDVM

52

7. Results of HLM using CDCAL

53

8. Hypotheses Results 


\section{CHAPTER I: INTRODUCTION}

Corporate Ventures are a form of entrepreneurship in which a corporation creates or acquires a wholly-owned new business and then allows it to operate independently of its parent (Kuratko et al. 2015). Corporate ventures (CVs) are an attractive option for established firms desiring to grow or diversify (Garrett \& Neubaum, 2013). Research shows that CVs have evolved over the past 40 years beyond their early role of developing value-creating innovations (Schollhammer, 1982). Other scholars have proposed CVs are now being utilized as vehicles through which corporations can gain knowledge (McGrath et al., 1994), achieve international success (Birkinshaw, 1997), and learn to configure resources innovatively to develop a competitive advantage (Kuratko et al., 2009). Scholars show that established corporations have three primary goals when starting CVs: 1) to increase the innovative capability of a firm; 2) to realize greater value from a parent's existing skills and resources by cultivating new knowledge in areas of strategic importance; and 3) to quickly generate financial returns (Miles \& Covin, 2002).

An underdeveloped but promising theory explaining the success some corporations can cultivate in corporate ventures is the parenting advantage. The parenting advantage is the amount of success that a $\mathrm{CV}$ achieves because of the particular corporate parent, it has and the amount of support it receives from that parent corporation (Campbell et al., 1995). This theory goes on to state that if a corporation has a parenting advantage its ventures will perform better than it would if it had a different 
corporate parent (Campbell et al., 1995). Thus, a parent corporation that can provide its ventures with more support and create more successful ventures has a parenting advantage over its competitors (Campbell et al., 1995). Further development of the theory has found that a corporation can obtain the parenting advantage in multiple ways; by providing complementary skills that a CV may not possess (Campbell et al., 1995), by providing market-specific expertise due to market relatedness of a venture (Garrett \& Covin, 2015), by providing specific resources to the endowment of a venture (Garrett \& Neubaum, 2013), or by providing specific knowledge that can benefit a venture (Tanriverdi \& Venkatraman, 2005). Although this theoretical lens provides valuable insights into how a corporation can create successful CVs by providing them with support, it fails to consider the impact relationship factors between a CV and corporate parent may have on the corporation's transfer of support and eventual venture success. We know that a parent corporation can obtain the parenting advantage and be more successful with its corporate ventures than its competitors by providing complementary skills and resources that a venture may not possess (Campbell et al., 1995). However, this theory currently hasn't been developed beyond this point, and we do not yet understand how the relationship between a parent and a venture can impact the transfer of beneficial resources from parent to venture. There could be characteristics of the relationship that inhibit the ability of a parent corporation to transfer the level of needed support to a venture. The theory to this point provides that a venture provides a parenting opportunity if a business can be improved beyond its current state (Campbell et al., 1995). We also know that a corporation can realize this opportunity if it possesses skills or resources that can improve the business (Campbell et al., 1995). An important 
assumption of the theory is that if a corporation has the complementary resources and a parenting advantage exists with a venture, it will transfer the beneficial resources and realize the parenting advantage. This assumption ignores the possibility that a parenting opportunity exists but that a corporation possessing beneficial resources is unable to transfer them to a venture. Expanding the theory to include how aspects of the relationship between two companies can inhibit the transfer of resources will further develop the theory.

A more holistic understanding of what factors can inhibit a corporation from transferring the parenting advantage to its ventures will allow us not only to understand why some corporations are more successful at venturing activities than others, but also why some ventures of a particular parent are more successful than their sibling ventures. Beyond the development of theory, there is a very practical reason to increase our understanding of how and why CVs fail or succeed. Corporations are engaging in venturing activities with purpose, and whereas, research supports venturing being a popular activity for corporations trying to grow, $\mathrm{CV}$ s continue to have very high failure rates (Hanan, 1976; Garrett \& Neubaum, 2013). A more developed understanding of why and how CVs fail or succeed can provide coachable insights to help corporations more successfully start new ventures.

To bridge this gap in theory and increase our understanding of what leads to venture success, I am adding the concept of cultural distance to the theoretical lens of parenting advantage. This motivates my primary research question which is:

\section{Research Question 1: What is the impact of cultural distance on the} performance of a $C V$ ? 
Varying levels of cultural distance between the parent corporation and its venture could be an aspect of the relationship that is impacting the ability of a parent corporation to transfer support to a venture. Culture is a set of important assumptions that members of a group share (Sathe, 1985). Research indicates that every corporate culture is unique and that it impacts its members (Schein, 1985). Cultural distance is the extent to which different cultures are similar or different (Shenkar, 2001). Corporate cultural distance is the amount of difference between two or more unique corporate cultures (Shenkar, 2001). In the management literature, cultural distance is shown to be a key antecedent of performance in relationships between culturally diverse corporations (Shenkar, 2001), including the performance of affiliated businesses (Black \& Mendenhall, 1991). For example, mergers and international joint ventures are like $\mathrm{CVs}$ in that they require multiple and diverse management teams to work together. These popular modes of exploiting new markets are shown to have failure rates as high as 70\% (Christensen et al., 2011; Lowen \& Pope, 2008). Research into the area has found that cultural distance significantly impacts the success that corporations engaging in these activities will achieve (Shenkar, 2001).

The need to learn through experimentation creates a CV culture wherein mistakes are tolerable so long as employees are learning from them (Simon et al., 1999). This willingness of a $\mathrm{CV}$ to learn through experimentation is in stark contrast to the stodgier character and bureaucratic policies typically associated with many large, established corporations (Simon et al., 1999). Large corporations traditionally have a rigid hierarchy, which impedes the nimbleness needed to make quick, flexible decisions (Simon et al., 1999). CVs require a unique culture from a parent corporation which the venture 
manager is responsible for developing (Shrader \& Simon, 1997; Simon et al., 1999). As an innovative firm, a CV's need for flexibility will create cultural distance from a parent that could create cultural friction.

Cultural friction is the amount of increase in resistance or animosity that can occur at the interface between interacting culturally different companies, which could increase the difficulty of communication, interaction, and information exchange (Shenkar, 2001, Luo \& Shenkar, 2011). This increase in the difficulty of interaction could worsen the relationship between the parties, as well as reduce the amount of information exchanged. Research to this point has not considered what impact cultural distance between an established corporation and its CV has on CV performance. However, the relationship between the two management teams impacts the potential benefits, if any, which will be transferred between an established corporation and its CV (Covin et al., 2016). In this sense, an important consideration is that before such a relationship can flourish, and both parties benefit, they must be able to interact harmoniously. To this point, we don't know what impact cultural distance from a parent corporation has on the success of a corporate venture.

I focus on the corporate cultural distance between an established corporation and its newly formed CV. When considering the impact of cultural distance, I consider that a culturally different $\mathrm{CV}$ may result in cultural friction occurring between the parent and its CV. I consider if this increase in cultural friction can act to inhibit the transfer of beneficial resources that a venture can receive from its parent and alter the amount of success the venture ultimately finds. 
Research shows that when a corporate parent creates a CV it is important to balance the autonomy of a $\mathrm{CV}$ with the amount of monitoring used to restrict a venture's options (Simon et al., 1999; Garrett \& Covin, 2015). When lack of balance is considered in conjunction with starting more CVs over time, especially when their performance is disappointing (Kuratko et al.,2009), it becomes increasingly apparent that a parent has an internal shortcoming leading to failure, perhaps serially, at corporate venturing activities. The cultural distance between a $\mathrm{CV}$ and its parent corporation, as well as the friction it creates, could lead to a lack of beneficial resources being transferred from the parent corporation and/or received by the venture. The additional strain of this could eventually lead to a dysfunctional relationship. I consider the impact of the congruence of perceptions and culture on the success of a CV. The theoretical lens that captures the importance of beneficial resource exchange between a parent corporation and its ventures is the parenting advantage perspective. The ability of a firm to overcome a strained relationship and receive the resources from a parent corporation is incorporated within the constructs of absorptive capacity and turbulence. This dissertation considers the relationship between cultural distance and performance as moderated by absorptive capacity and turbulence.

\section{The Impact of Absorptive Capacity on the Relationship Between Cultural}

\section{Distance and the Performance of a $\mathrm{CV}$}

Absorptive Capacity is the corporate capacity to utilize external knowledge during the successive learning processes; 1.) exploration, 2.) transformation, and 3.) exploitation (Lane et al., 2006; Lichtenthaler, 2009). Research shows that absorptive capacity is the aggregation of this learning process through which a corporation derives its ability to 
obtain, assimilate, and stockpile knowledge (Lane et al., 2006). In the relationship between the $\mathrm{CV}$ and parent corporation, having cultural distance may provide an opportunity for the venture to learn from their parent (March, 1991) while altering their culture to include new processes and structures (Kuratko \& Audretsch, 2013). The level to which the venture management team can acquire and incorporate information from the parent could impact the extent to which its venture is able to benefit from the parenting advantage the parent corporation has to offer. Research into the area suggests that the amount of information exchanged is positively correlated with better firm performance (Kuratko et al., 2009).

\section{The Impact of Turbulence on the Relationship Between Cultural Distance and the Performance of a $\mathrm{CV}$}

Turbulence is the combination of; 1.) the extent to which the composition and preferences of a corporation's customers change over time, 2.) the behavior, resources, ability of competitors to differentiate; as well as 3.) the extent to which technology in an industry is in a state of flux (Jaworski \& Kohli, 1993). Research shows that during times of high environmental turbulence, corporations are more likely to seek out innovative opportunities (Kuratko et al., 2014b). The level of turbulence could impact the extent to which venture managers are open to and/or actively seek out the opportunity to gain information from their corporate parent. These varying levels of turbulence could lead to a change in feeling the "need" to learn and change by upper management. A change in felt-need by management to gain and disseminate new knowledge may alter the amount of change through nurturing a parent makes on the processes and structures of a venture. Whereas, learning occurs at the individual level, for the learning to change processes and 
structures, which are engrained in culture, the learning has to pass from management through the corporation (March, 1991). Under pressure for a venture to perform and with the added stress of environmental turbulence, managers may be more aggressive in trying to gain new knowledge and more proactive in distributing this learned knowledge through the ranks of a venture.

\section{The Impact of Perceived Cultural Distance Congruence on the Relationship Between Cultural Distance and CV Performance}

The unique perceptions of a manager impact his or her views of success (Bantel, 1998), and the strain created by cultural distance is shown to be a key contributor to success (Shenkar, 2001). In the instance of a CV, this strain can occur due a lack of congruence between a $\mathrm{CV}$ manager and the manager of the parent corporation. A strain between the nuanced aspects of personal relationships between a parent corporation and a CV can lead to difficulties in nurturing a CV (Sherman, 1992). Congruence of perceptions of cultural distance between the managers of a parent corporation and a $\mathrm{CV}$, independent of the amount of cultural distance, could alter the way the two sides communicate and interact with each other. 


\section{Research Model}

Figure 1. Research Model

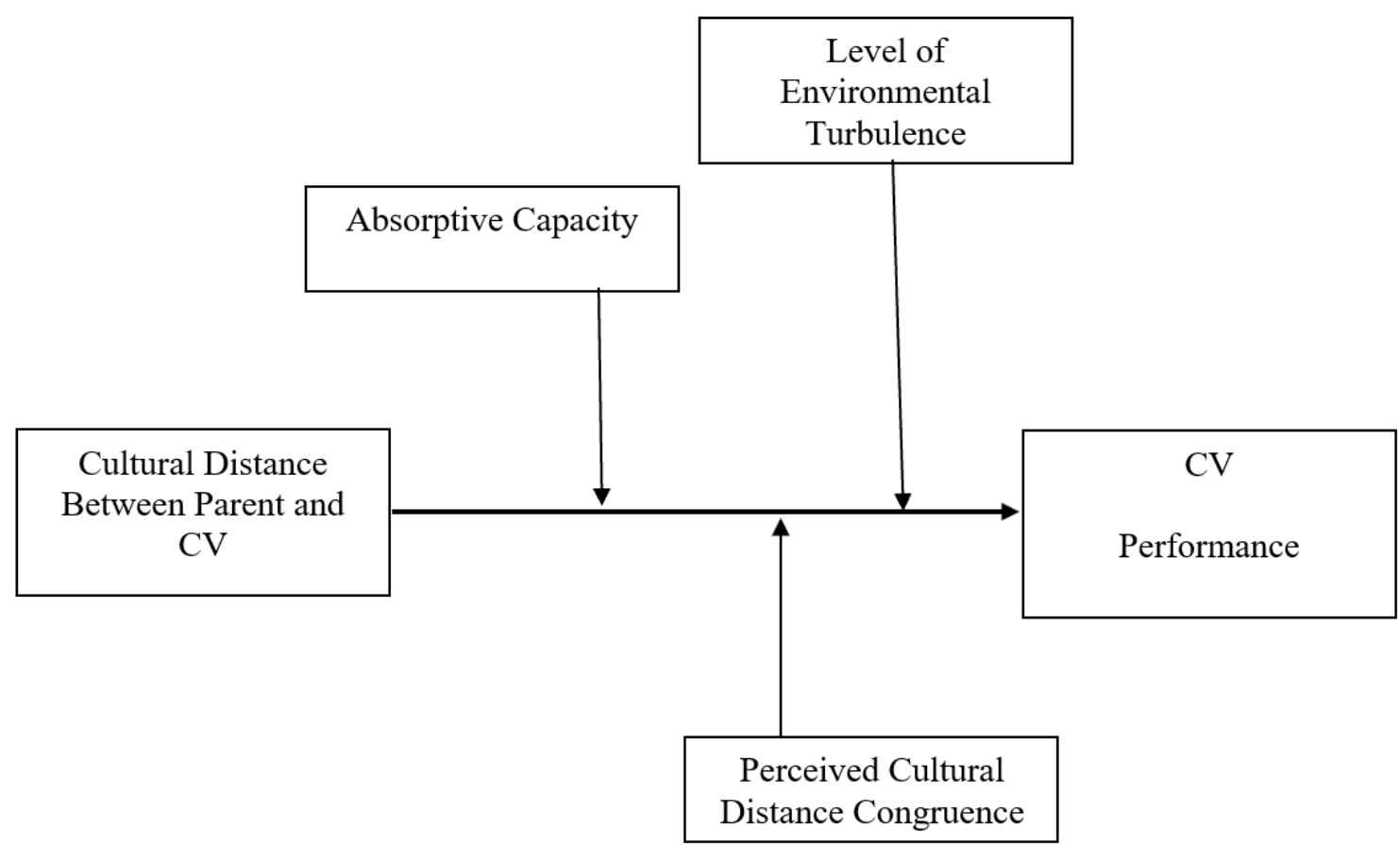

\section{Intended Contributions}

The primary intended contribution of this dissertation is to further develop the perspective of parenting advantage. Although it shows parenting is a way corporations can more successfully start ventures by nurturing these ventures and providing their venture offspring with complementary resources and skills (Campbell et al., 1995), it has not been developed extensively past this point. A goal of this research is to develop the parenting advantage perspective beyond its current considerations. In this research, I attempt to extend the perspective past thinking in terms of solely whether a corporation is a good or bad parent or does that corporation have complementary resources with which to properly nurture its ventures. This research considers what seems a more likely option that all corporate parents have some amount of complementary resources or advantages 
they can offer to their ventures, but there is some aspect of the relationship between the parent and child that is inhibiting this nurturing from being transferred from the parent to child. I do this by considering the impact of cultural distance between a parent and its venture which has been correlated with negative child outcomes between culturally distant human parents and their children (Kim et al., 2006; Tseng \& Fuligni, 2000).

Although the body of CV research has provided many insights, scholars continue to cite the same problem of high failure rates with CVs (Hanan, 1976; Lowen \& Pope, 2008). The relationship between corporate and venture managers is essential to the success of a CV (Sherman, 1992). However, studying this relationship has proved to be difficult. A goal of this research is to better understand the relationship between the two managers and what impact cultural distance has on this relationship. By understanding the impact of cultural distance, I hope to determine to what extent an increase in cultural distance and friction has on the amount of success a venture can have. If the reason a venture is unable to receive the optimum level of nurturing from its parent corporation is friction inhibiting the transfer process, it is coachable and a problem that can be overcome.

A better understanding of this relationship will make both theoretical and practical contributions. This research focuses on the relationship and/or relational strain between corporate and venture managers, which is an aspect of venturing activities that managers can be coached on and improve. Advancing the understanding of how cultural distance can impact the relationship between a parent and CV managers and eventually on venture success will provide an opportunity to improve CV success rates. The relationship between the two managers is paramount in the success yet the intricacies that 
lead to the success or failure of the relationships are not well understood. The practical contribution is that a better understanding of this relationship will allow us as scholars and educators to make more cogent recommendations to current and future executives that will be charged with the success of future CVs. The ultimate goal is that this research can lead to decreasing the failure rate of future CVs.

This study will make contributions to corporate managers. Research indicates that there is no link between the number of CVs a corporation previously started and the success they achieve through each CV (Kuratko et al., 2009). This could imply that there are inherent characteristics of corporations that greatly impact their likelihood of launching successful CVs. These characteristics and their nuances may be captured in corporate culture. By providing managers with a better understanding of the impact of cultural distance as well as the congruence of distance perceptions between parent and $\mathrm{CV}$ managers, I can provide a basis for enacting change on parent corporation-CV relations. Learning can come from someone outside the current corporate culture (March, 1991), and learning is shown to impact the level of success a CV obtains (Covin et al., 2016). Also, learning by the parent corporation is a measure of the success of a CV (Keil et al., 2009). Through increasing corporate managers' understanding of the roles cultural distance and absorptive capacity have on performance, we may be able to foster an environment of understanding and increased information exchange between parent corporations and CVs.

Cultural distance is one of the most considered constructs in international business research (Shenkar, 2012). Despite CVs being used as vehicles through which corporations can achieve international success (Birkinshaw, 1997; Callaway, 2008), and 
the widely accepted fact that large corporations and their CVs have different corporate cultures (Simon et al., 1999; Garrett \& Covin, 2015), it has yet to be included in the CV literature. This study uses multiple measurement methods to determine the cultural distance between parent corporations and their CVs and the impact that this distance has on $\mathrm{CV}$ performance. By including international data, I hope to further increase the generalizability of this study.

A common complaint within the $\mathrm{CV}$ literature is that there is a failure to use multiple sources of data and limited alignment with major theoretical streams (Ireland \& Webb, 2007; Hill \& Georgoulas, 2016). This study will contribute to overcoming this challenge in multiple ways. First, this study aligns with major theoretical streams by including variables of cultural distance and absorptive capacity. Absorptive capacity is a construct of interest when considering a relationship between two culturally diverse corporations (Bjorkman et al., 2007). The relationship between a CV and parent corporation is a complex relationship between two culturally diverse companies, yet the impact of absorptive capacity on the performance of CVs has not been heavily explored. This study will advance the current literature through both improving our understanding of the relationship between absorptive capacity and performance, and also how absorptive capacity moderates the relationship between cultural distance and CV performance. 


\section{CHAPTER II: LITERATURE REVIEW AND HYPOTHESIS DEVELOPMENT}

\section{Literature Review}

In this chapter, I provide a review of the pertinent literature and later develop the hypotheses of this study. I organize the literature review into four subsections: the foundation of $\mathrm{CV}$ research, learning and $\mathrm{CV}$ s, internationalization and $\mathrm{CVs}$, and the antecedents of $\mathrm{CV}$ success. The foundations of $\mathrm{CV}$ research include some of the earliest and most influential work into corporate venturing. Because the scope of this project is international, I review the literature of CVs being used to enter international markets. Also, I introduce in this study cultural components and cultural distance as antecedents to CV success. I review the antecedents other scholars have proposed and studied as predictors of $\mathrm{CV}$ performance.

\section{Foundation of CV Research}

Corporations, in part, use CVs as a way to diversify (Schollhammer, 1982).

Acquisitions have long been thought to be a good option for diversification (Schollhammer, 1982). However, high failure rates and complications with antitrust laws led corporations to explore other means to diversify (Adams, 1969; Hanan, 1976). Early CVs also had unsatisfactory results, with many of the early movers having nothing to show for their efforts and then canceling all their venturing activities (Hanan, 1976). It was also found that CVs were subject to early termination even though studies showed a CV on average required eight years to prove its worth (Burgerdike, 1979). From 
interviews with corporate managers, researchers ascertained that part of this problem was due to CVs being treated like smaller multinational firms with the same departments and resource allocation structure (Hanan, 1976). Researchers have determined that major corporations are not natural habitats for entrepreneurial activities and that CVs need to be treated more like start-ups than smaller clones of major corporations (Hanan, 1976). The bureaucratic conditions that exist in many large corporations create a hostile environment for innovation (Hlavecek \& Thompson, 1978). Major corporations operate under a very rigid business plan, which works well for established businesses, but CVs need room to be flexible and adapt to the environment to be able to succeed (Hanan, 1976, Honig \& Karlsson, 2004). CVs were found to need a different style of manager, organization, and objective structure than its large parent corporation (Hanan, 1976). The conclusion that a $\mathrm{CV}$ needs a different type of manager formed the basis of modern $\mathrm{CV}$ research. While a $\mathrm{CV}$ can be useful for a large corporation, it can also be difficult to implement. The difficulty of implementing a $\mathrm{CV}$ is due in part to the $\mathrm{CV}$ needing to be so different from the parent corporation yet still overseen by a parent who may not fully understand a CV's needs (Fast, 1979; Garrett \& Neubaum, 2013).

Further research suggested that the involvement of parent corporation management could have a significant impact on the success that a CV ultimately achieves (MacMillan \& George, 1985). Earlier research had indicated that a primary cause of failure with CVs was the frequent interference of parent corporation managers (Burgelman, 1983). While later research concurred that interference could increase failure rates of $\mathrm{CVs}$, studies also found that total neglect had similarly negative results (MacMillan \& George, 1985). It was determined that parent corporation management 
faced the difficult challenge of balancing the amount of management and oversight they provided to the CV (MacMillan \& George, 1985). Researchers also determined that parent corporations needed to understand the amount of support a CV would need in order to have an opportunity to succeed (MacMillan \& George, 1985).

\section{Learning and CVs}

Although the majority of $\mathrm{CV}$ research has focused on business growth and financial performance, it has been suggested that a primary role of a $\mathrm{CV}$ is to provide a vehicle through which an existing corporation can generate new abilities and knowledge (Keil et al., 2009). Further research from Keil et al. (2009) suggested that failure is part of the natural lifecycle of ventures and that the benefits corporations can garnish from CVs are not correlated with the CV's market success. This research focuses on the learning that occurs at the level of the parent corporation. Other scholars have focused on how learning impacts the survivability of a CV (Gupta et al., 2006; Hill \& Birkinshaw, 2014). The learning process is not simple; it involves many nuances and complexities. A CV may be engaging in learning activities to develop its own new market knowledge (Gupta et al., 2006). This knowledge can then be assimilated and utilized through the learning activities of the parent corporation (Gupta et al., 2006). Learning is not inherently a trait of a corporation, but rather a function of individuals. Within a $\mathrm{CV}$ it may be necessary to have different types of people or skills to obtain the proper level of balance among learning activities (Gupta et al., 2006).

Recent research has extended this work into learning by considering the extent to which ambidexterity between learning activities leads to the ability of a CV to endure (Hill \& Birkinshaw, 2014). Whereas the primary responsibility of a CV may be to 
provide new opportunities for the parent corporation, the $\mathrm{CV}$ is also responsible for utilizing the existing resources of the parent corporation to make advancements more effectively (Hill \& Birkinshaw, 2014). Also, a CV should find ways to exploit its investments to benefit the parent firm (Hill \& Birkinshaw, 2014). This research also found that the survivability of a CV was reliant on multiple antecedents, including the ability of the CV to use the parent corporation's existing capabilities to develop new capabilities and the extent to which the CV could integrate its activities with other units within the corporation (Hill \& Birkinshaw, 2014). The ability of a CV to coordinate its activities with the activities of both a parent corporation and other CVs greatly increases the likelihood that a CV endures and has an ongoing role with its parent corporation (Hill \& Birkinshaw, 2014). The irony is, that although CVs are often seen as a way for parent corporations to improve their ambidexterity, it may very well be balanced ambidexterity that leads to the survivability of CVs (Hill \& Birkinshaw, 2014).

\section{CVs as a way to Enter International Markets}

Multinational enterprises often desire to spread their costs over large customer bases (Hitt et al., 2006). This desire can drive multinationals to take current product offerings and expand them into new markets. One method of entering new markets is for corporations to establish global ventures, which are CVs started specifically to enter a new international market (Callaway, 2008). Although corporations may prefer to enter international markets slowly, global competition can necessitate that they enter more quickly. More often firms are pressured to expand their markets internationally early in their history to remain competitive (Oviatt and McDougall, 1994). CVs require a different culture from their parent corporations. Similarly, companies entering a new 
international market may require a different culture to succeed than the parent corporation. The usage of CVs to enter new international markets may provide established corporations a vehicle through which to access these markets which is more adaptable than the established corporation (Callaway, 2008). Likewise, a CV has the advantage of the parent corporation's established resources to help facilitate its entry into the new market (Callaway, 2008).

\section{Antecedents of Success}

Research into CVs has identified several antecedents and correlates indicating the success of a CV. Uncommitted financial resources and opportunities within a parent corporation's core business are associated with more successful CVs (Kuratko et al., 2009). Research stipulates that when opportunities lay within the purview of a parent corporation's core businesses the parent was less likely to engage in counterproductive meddling which helped the CV to be more successful (Kuratko et al., 2009). Operating within a market or product that is adjacent to that of the parent corporation has long been regarded as an antecedent to CV success (Thornhill \& Amit, 2001; Hill \& Birkinshaw, 2008). However, empirical research has found very little support that product similarity and market familiarity are associated with the survivability of a CV (Kuratko et al., 2009). The degree to which a CV was a planned strategic initiative was shown to positively impact the success of a CV (Kuratko et al., 2009). It was stipulated that this could be due to a parent corporation viewing a strategically planned $\mathrm{CV}$ as more legitimate and more adequately providing the necessary funding for such ventures (Kuratko et al., 2009). 
The literature to this point has continued to support that the degree to which the $\mathrm{CV}$ has the support of the top management of its parent corporation is a key factor in $\mathrm{CV}$ success (Shrader \& Simon, 1997; Kuratko et al., 2005; Kuratko et al., 2009). The natural turnover of upper-level management and the lifecycles of a new investment venture can unfortunately often lead to a lack of needed support. Research has found that the average cycle of change for a corporation's CEO is six years (Kaplan \& Minton, 2006) and that the average start-up investment will not show a positive yield until year seven or eight (Gompers \& Lerner, 1998, 2001). Clear communication of the goals and value propositions for a $\mathrm{CV}$ from parent company managers to $\mathrm{CV}$ managers has a high correlation with venture performance (Kuratko et al., 2009; Covin et al. 2016).

Early research into the topic determined there was a strong correlation between CV performance and operational relatedness with a parent corporation (Sorrentino \& Williams, 1995). Since then, empirical work on the topic has found that CV organizational autonomy from the parent corporation is correlated with better $\mathrm{CV}$ financial performance (Hill et al., 2009; Kuratko et al., 2009). It has been found that higher levels of venture specific knowledge by parent corporation management and general managerial skills are positively correlated with better CV performance (Kuratko et al., 2009; Riley et al., 2009). Unsurprisingly, both the parent corporation possessing the strategic resources necessary for success in the CV's business and providing the CV with a sufficient initial endowment of these strategic resources has been correlated with better CV performance (Kuratko et al., 2009). To this point, research has found a negative impact of both environmental hostility and dynamism on the performance of a CV (Covin et al., 2016). 


\section{Parenting Advantage}

The parenting advantage was developed as a method for corporations to decide the fit of a potential new venture for them by evaluating if they have a parenting advantage with that business (Campbell et al., 1995). The theory states that if a corporation has a parenting advantage over its competitors then they will create more value for a particular venture than if any of their competitors created the same venture (Campbell et al., 1995). For a parent corporation to have a parenting advantage the venture has to provide them with a parenting opportunity, signifying that there is room for the venture to be improved (Campbell et al., 1995). The parent corporation is then able to gain a parenting advantage if a parenting opportunity exists and they have complementary resources or skills with which they can share with the venture to improve it (Campbell et al., 1995). This research has been extended over the past several years. The parenting advantage has been applied to the parent corporation providing complementary assets to a firm enabling the increase in technological developments (King et al., 2003). Beyond just having complementary skills and resources to provide to a venture, research has also found that a corporate parent can achieve a parenting advantage through the initial strategic asset endowment that they provide to the venture (Garrett \& Neubaum, 2013). The amount of parenting advantage a parent corporation has was also argued to be impacted by the amount of embeddedness that the venture and corporate parent share in the same network (Nell \& Ambos, 2013).

\section{Development of Hypotheses}

\section{Corporate Cultural Distance}


The parenting advantage has become a popular perspective to explain the success that a corporation has creating new ventures (Campbell et al., 1995; Nippa et al., 2011). The perspective of parenting advantage states that a venture can receive nurturing from a parent corporation (Campbell et al., 1995). Some parent corporations have a parenting advantage, whereby the best parent corporations will create more value for a venture than if any of their rivals owned the same business (Campbell et al., 1995). This perspective includes the corporation providing complementary services or resources to a venture that the venture may not possess (Campbell et al., 1995). However, there is more to parenting than just having resources that can benefit your offspring. Equally important is that you be able to transfer these resources that you have to your offspring for them to receive the benefit of having a good parent.

Further research into corporate venturing shows that there is no correlation between a corporation starting more ventures and a corporation starting more successful ventures (Kuratko et al., 2009). This, in conjunction with the parenting advantage perspective, can be interpreted in multiple ways. I have interpreted the work of Kuratko et al. (2009) that venturing is difficult, and each individual venture presents a unique corporation-CV culture dyad. For this reason, it is difficult to learn from one venture and apply that learning to future ventures. My interpretation, from these two streams, is that most if not all corporations have some knowledge or resources to offer their ventures. However, in some parent venture relationships, something is inhibiting the parent from transferring their advantage to their offspring. Cultural distance between a parent corporation and their venture could be one factor that is impacting the ability of a parent corporation to transfer the resources they have to their ventures. Cultural distance has 
been shown to create cultural friction between two culturally different interacting parties (Shenkar, 2001). A corporation starting a new CV is acting both as a parent and a business having interactions with a culturally different business. Cultural distance is shown in business research to impact the success of the relationship between two culturally different businesses (Shenkar, 2001). Also, social research into the parenting paradigm in humans shows that cultural distance between a parent and child is correlated with negative child outcomes (Kim et al., 2006; Tseng \& Fuligni, 2000).

CVs are a popular option for established corporations to exploit a myriad of potential opportunities (Garrett \& Neubaum, 2013). The necessity of a CV to be innovative and learn through failure sets the culture of a $\mathrm{CV}$ apart from that of an established corporation. The typical established corporate cultural structure, including well-defined boundaries and rigid hierarchies, is not conducive to entrepreneurial efforts (Dess et al., 1999). In stark contrast to this, firms that are entrepreneurial tend to exhibit characteristics of dynamism and flexibility and are prepared to capitalize on new opportunities when they arise (Kuratko et al. 2012). For this reason, even though innovation and entrepreneurship are viewed as necessary strategies for firms competing in today's marketplace, successful execution of CVs remains difficult for most corporations (Kuratko et al., 2014a). CVs create a situation where the established corporation must delicately balance the entrepreneurial initiative's need for independence with the corporation's need to manage and mitigate costs and risks (Garrett \& Covin, 2014). The stark contrast in corporate cultures that exist between established corporations and their entrepreneurial CVs necessitates the understanding of the impact cultural distance has on this delicate relationship. 
The need for a $\mathrm{CV}$ management team to tolerate failure in the name of learning and innovation is very much a different way of approaching business than that associated with established corporations. The disparity between these two cultures is likely to create a level of friction between the two management teams. This friction caused by different cultures could deteriorate and strain the relationship between the parent and CV. A strained relationship could prove problematic as research has found that CVs need parent support to succeed (Kuratko et al., 2009), and that parent corporations can gain novel information from their CVs (Keil et al., 2009). If the distance between the two corporate cultures is reducing the amount of information and resources that are being transmitted between a $\mathrm{CV}$ and parent corporation, then the distance will in turn create a situation where a $\mathrm{CV}$ performs poorly. This poor performance would manifest both in terms of its own lower financial returns and survivability.

A common problem with cultural distance research is that cultural distance is measured from a single common culture to multiple different cultures (Brouthers et al., 2016). In the case of considering CVs, this would be equivalent to measuring only from the established corporations to the multiple cultures of its CVs. This strategy ignores the perceived cultural distances from a $\mathrm{CV}$ to the established corporation. This is problematic because it assumes symmetry when considering the measure of cultural distance. Distance by definition is symmetric, and the assumption is that the distance from culture A to culture B is the same as the distance from culture B to culture A (Shenkar, 2001). However, there are no studies showing this symmetry exists when considering cultural distance and there is no reason to assume that this symmetry exists (Shenkar, 2001). This assumption of symmetry would imply that the distance from an 
established corporation to a $\mathrm{CV}$ is the same as the distance from a $\mathrm{CV}$ to a corporation. This could be untrue in part because culture includes many nuances and is subject to the perceptions of both the corporate and joint venture managers. To address the concern of asymmetry in cultural distance I propose hypotheses considering cultural distance from the perspective of both the corporate and venture manager, as well as a calculated measure of cultural distance which will assume symmetry in cultural distance. To calculate the measure of cultural distance I will collect the corporate and CV manager's perceptions of the culture for their own company and then calculate the absolute distance between the two cultures.

\begin{tabular}{|c|c|c|}
\hline Corporate Manager's & H1a. & $\mathrm{CV}$ \\
\hline Perceived Cultural & & Performance \\
\hline Distance & & \\
\hline
\end{tabular}

\begin{tabular}{|c|c|c|}
\hline CV Manager's \\
Perceived Cultural \\
Distance
\end{tabular}$\quad$ H1b. $\quad$\begin{tabular}{c} 
CV \\
Performance \\
\hline
\end{tabular}

\begin{tabular}{|c|c|c|}
\hline $\begin{array}{c}\text { Measured Cultural } \\
\text { Distance }\end{array}$ & H1c. & PV \\
Performance
\end{tabular}


Hypothesis 1a: There is a negative relationship between the corporate manager's perceived cultural distance and CV performance.

Hypothesis 1b: There is a negative relationship between the CV manager's perceived cultural distance and $\mathrm{CV}$ performance.

Hypothesis 1c: There is a negative relationship between measured cultural distance and $\mathrm{CV}$ performance.

\section{Absorptive Capacity}

If a venture is to receive advantages from its parent, not only does the parent have to be willing to nurture the venture, but also the venture will need to accept nurturing. Within the closed system of a corporation, over time the culture of the individuals and the organization will become a singular homogenous culture (March, 1991). The culture can only change when acted upon by individuals whose culture deviates from that of the group (March, 1991). The culture of the parent through parenting can act upon the venture and through the process transform the organizations and processes of the venture. This transformation of a corporation's internal organizations can become what differentiates a venture from its competitors (Kuratko et al., 2015). This could prove beneficial to the venture since successful corporate entrepreneurship can not only lead to innovation in product offerings and markets, but also in internal organizations such as processes and structures (Kuratko \& Audretsch, 2013).

One potential benefit of cultural distance between a parent corporation and a corporate venture is the opportunity to gain information (March, 1991). Since the parent will have a different culture and likely different knowledge, the opportunity exists for the parent corporation to transfer and augment the knowledge stockpile of the CV. Research 
has shown that corporations are relying on external knowledge to improve performance at an increasing rate (Ireland et al., 2002; Zollo et al., 2002). Research shows that some firms can derive great benefit from external knowledge (Cassiman \& Veugelers, 2006). Managerial relationships are shown to impact the amount of interfirm knowledge transfer that occurs (Cohen \& Levinthal, 1990). As a result of this constraint, the absorptive capacity of a corporation can become a competitive advantage for the corporation (Zahra \& George, 2002).

Absorptive Capacity is the ability of a corporation to utilize external knowledge through the successive learning processes (Lane et al., 2006). Learning is a multi-level process that consists of acquiring, assimilating, and retaining new information (Lane et al., 2006). Exploratory learning is the process through which corporations acquire new external knowledge (Zahra \& George, 2002). Exploitative learning is the process through which the corporation assimilates external knowledge and applies it to the corporation's specific markets (Lane et al., 2006; Lenox \& King, 2004). Transformative learning links exploitative and exploratory learning; it is the process of retaining acquired and assimilated knowledge over time (Lane et al., 2006). The result of these learning processes, absorptive capacity, has been shown to have an impact greater than any individual learning component as they gain synergy from complementarity and balance (Lichtenthaler, 2009).

The learning capabilities of managers are associated with better performance of CVs (Kuratko et al., 2009; Riley et al., 2009). Because absorptive capacity is a representative measure of management's ability to utilize each of the learning processes, it is an appropriate construct for this study. The level of absorptive capacity that each CV 
management team possesses could be indicative of the amount of nurturing that the $\mathrm{CV}$ will be able to receive from their corporate parent. The presence of cultural distance between a $\mathrm{CV}$ and parent corporation could provide a prime opportunity for a venture to gain external knowledge. The amount of absorptive capacity of the venture could impact to what degree the venture will be able to capitalize on this opportunity and gain benefit from its parent's knowledge. Also, the absorptive capacity of the CV could be indicative of whether the $\mathrm{CV}$ will abstain from assimilating to the parent corporation's culture and continue to resist the opportunity to learn and incorporate cultural change from their parent. As such the amount of absorptive capacity a venture has will moderate the impact cultural distance from the parent has on the success outcomes of the venture.

Hypothesis 2a: The absorptive capacity of the CV manager moderates the negative relationship between the corporate manager's perceived cultural distance and $\mathrm{CV}$ performance and makes it less negative when the absorptive capacity is lower.

Hypothesis 2b: The absorptive capacity of the CV manager moderates the negative relationship between the CV manager's perceived cultural distance and $\mathrm{CV}$ performance and makes it less negative when the absorptive capacity is lower.

Hypothesis 2c: The absorptive capacity of the CV manager moderates the negative relationship between measured cultural distance and $\mathrm{CV}$ performance and makes it less negative when the absorptive capacity is lower.

\section{Turbulence}


There is a lag between learning and change in culture (March, 1991). Learning can occur at the individual level. However, for this to change corporate culture, the learning will have to be disseminated throughout the corporation (March, 1991). Research shows environmental conditions, such as turbulence, can impact to what degree corporations seek out innovative activities and the rate at which they gather and disseminate information (Kuratko et al., 2014a). Turbulence as proposed by Kohli \& Jaworski (1990), has three components: market turbulence, competitive intensity, and technological turbulence. Turbulence is the combination of the extent to which the composition and preferences of a corporation's customers change over time, the behavior, resources, and ability of competitors to differentiate, as well as the extent to which technology in an industry was in a state of flux (Jaworski \& Kohli, 1993). A potential benefit of operating in high turbulence is it can increase the rate and amount of change that occurs in a venture's culture. Turbulent environments require that a company adapt to the external environment and can lead managers to seek out new information and opportunities to learn. Research has shown that in times of high environmental turbulence, corporations will more actively seek out innovative activities (Kuratko et al., 2014a). This need to actively innovate in a turbulent environment could alter the level of impact cultural distance has on the amount of success that a venture realizes.

Corporations seek out innovative activities because unpredictable market conditions lead to corporations not only being challenged to grow and venture but also for the survival of the organization (Kuratko et al., 2014b). This could indicate that in times of high environmental turbulence or in industries that are inherently turbulent, managers may be more open to seeking out different and even radical ideas. The impact 
of environmental turbulence is twofold. First, firms have been shown to place different values on their dynamic capabilities in turbulent environments (Eisenhardt \& Martin, 2000). Second, in turbulent environments, it is more difficult for other firms to imitate the actions of a firm, increasing the level of sustainability of any advantage created in a turbulent environment (Helfat et al., 2009; Song et al., 2005). In a turbulent environment, there may be a difference in the level of perceived opportunity to learn for venture managers from the ideas of a culturally different parent.

When a corporation is engaged in corporate venturing and the venture operates in high environmental turbulence, the venture manager may more actively seek external knowledge from the corporate parent. Also, if a CV is operating in a turbulent environment it may be more innovative than a $\mathrm{CV}$ in a less turbulent environment. This would create a situation where a CV is generating innovation and knowledge at a high rate and also seeking external knowledge at a high rate. The need to survive in turbulent environments could increase the level of tolerance for cultural friction from both managers and reduce the impact cultural distance has on the success of the venture. While cultural distance would still exist between a parent and its CV, a high level of environmental turbulence could facilitate an improved relationship between the management teams leading to increased sharing between the two and a more successful venture.

Hypothesis 3a: The level of turbulence moderates the negative relationship between the corporate manager's perceived cultural distance and $\mathrm{CV}$ performance and makes it less negative when turbulence is higher. 
Hypothesis 3b: The level of turbulence moderates the negative relationship between the CV manager's perceived cultural distance and $\mathrm{CV}$ performance and makes it less negative when turbulence is higher.

Hypothesis 3c: The level of turbulence moderates the negative relationship between measured cultural distance and CV performance and makes it less negative when turbulence is higher.

\section{Congruence}

Cultural distance research identifies one of the primary adverse effects of an increase in cultural distance is the decrease of ease of communication between two parties (Shenkar, 2001). The degree to which culturally distant managers agree on the amount of cultural distance that exists could facilitate understanding and empathy and reduce the amount of difficulty the managers have communicating. Greater ease of communication between the managers could reduce the negative impact cultural distance has on their relationship. This work was originally referring to the relationship between corporations in multiple countries that would obviously have varying national cultures. In this research, I extend this into the divergence of cultures that can occur between a traditional corporation and their newly-created CV. Potentially the largest cost of friction between a parent corporation manager and a CV manager would be the straining of the relationship to the extent it causes a failure of a CV. Research supports this by showing that the difficulties associated with CVs can be partially derived from nuanced sources such as strained personal relationships between managers instigated in part by divergent corporate cultures (Sherman, 1992; Tallman \& Shenkar, 1994). 
A CV manager serves in the role of a professional manager for the parent corporations' wholly-owned CV. Scholars have shown that there is a benefit to having a professional manager (Fama \& Jensen, 1983). A strained relationship between the professional manager of a $\mathrm{CV}$ and the corporate manager could decrease the amount of benefit the corporation receives from its professional venture manager. This implies obtaining congruence between the distant parties could have positive impacts on performance. Congruence as to the amount of distance that exists could increase the understanding and empathy between managers and lessen the intensity of the impact of cultural distance on the relationship. While cultural distance between a parent corporation and a CV seems necessary, cultural friction, which is correlated with negative results, is not necessary. Cultural friction only occurs when the two cultures clash during interaction (Shenkar, 2001). A possible contributor to an increase in the amount of cultural friction between culturally different companies is a lack in the amount of symmetry of perceived cultural distance. When asymmetry increases it would manifest itself as a decrease in the level of congruence in the perceptions of the corporate and venture manager as to the amount of cultural distance that exists between the two companies. Thus, one manager would perceive the amount of distance to be significantly larger or smaller than the other manager and be less understanding and empathetic. Moving between cultures often requires a degree of translation; however, translations may not always be perfect. Congruence of the managers' perceptions of distance could facilitate the managers having higher levels of understanding and empathy and even though cultural distance exists if may have a less negative impact on the relationship and not impede successful outcomes. 
Hypothesis 4a: The level of cultural distance congruence will moderate the negative relationship between the corporate manager's perceived cultural distance and $\mathrm{CV}$ performance and makes it less negative when congruence is higher.

Hypothesis 4b: The level of cultural distance congruence will moderate the negative relationship between CV manager's perceived cultural distance and $\mathrm{CV}$ performance and makes it less negative when congruence is higher.

Hypothesis 4c: The level of cultural distance congruence will moderate the negative relationship between measured cultural distance and CV performance and makes it less negative when congruence is higher. 


\section{CHAPTER III: METHODS}

This project relies on data collected through electronic surveys. I have collected unique, dyadic survey data from both United States parent corporations and their CVs as well as international parent corporations and their CVs. Collecting an international dataset both increases the applicability of research and reduces the limitations of my research. This study utilizes dyadic data collected from both the parent corporation and the $\mathrm{CV}$.

The Mergent Intellect Database was used to identify companies to target for participation in this project. This database was appropriate for the scope of this project as it included information on over 245 million companies throughout the world. The database included information at both the corporation and executive levels. The corporation level information included address, SIC codes, annual sales, and other identifying information. The executive-level information included the title and contact information of key executives. In the instance of US companies, the executive title in combination with the size of the company was used to identify corporations that were likely involved in corporate ventures.

It was possible that this data collection would have occasionally required inperson visits either initially or as a followup. For this reason, companies were originally selected regionally to be near the university in the US or near the institution of the international-contact assisting with data collection. In the US, the firms that were 
identified fell into a twelve-state region that included West Virginia, Virginia, Tennessee, Georgia, Kentucky, Indiana, Ohio, Illinois, Arkansas, Texas, North Carolina, and Missouri. This research assumed that this is a broad geographic region containing a diverse set of corporations and did not reduce generalizability.

There is a precedent in the literature to support conducting $\mathrm{CV}$ research on samples of very large corporations. Previous research has utilized the companies found in the Fortune 500 (e.g., Von Hippel, 1977; Klavans et al., 1985) or a list of the largest corporations in a country (e.g., Thornhill \& Amitt, 2001). Also, research indicates that only large corporations are likely to have sufficient resource bases to support CV activities (Burgelman \& Valikangas, 2005). Following this trend, I have designed my study to only include firms with $\$ 50$ million or more in sales. To provide consistency among the data, firms in all countries were selected for inclusion using the same sales level. Additionally, among the US firms more extensive job title information is provided and the pool for potential targets was confined to corporations with an executive title indicative of a corporation engaging in CVs. The executive titles provided by Mergent that were indicative of corporate venturing are Business Development Director, VP of Corporate Development, and VP of Product Development.

To verify that the companies are involved in corporate venturing and to solicit their participation in the survey, I contacted each of the identified companies. The countries originally included in this project were The United States, Italy, Canada, Germany, Spain, Mexico, Singapore, and Brazil. The preliminary number of corporations identified per country is indicated below in Table 1. To aid in overcoming 
survivor bias, each identified corporation was asked not only to report on ongoing ventures but ventures that have been terminated as well.

Table 1. Companies Identified per Country

\begin{tabular}{|c|c|}
\hline The United States of America & 688 \\
\hline Canada & 508 \\
\hline Italy & 543 \\
\hline Spain & 382 \\
\hline Germany & 372 \\
\hline Mexico & 444 \\
\hline Singapore & 387 \\
\hline Brazil & 454 \\
\hline
\end{tabular}

Initial calls were made to the originally identified corporations, with the intent to send emails with invitations to participate in the research project. Due to intensive screening protocols at these companies, I had to employ other tactics. Although I could find the executive responsible for pursuing corporate ventures, there were rarely directline or email information provided so I would be relegated to talking to an operator or administrative assistant. Corporations were then very guarded in granting me contact with the executives themselves, but rather their assistant, so I couldn't make my direct pitch to the person I needed participation from. I used international partners at partnering universities to gain participation in Mexico and Italy. I also used job title searches in LinkedIn to send network requests to executives in charge of corporate venturing. In LinkedIn, I had a total of 890 executives that either accepted my request to join my network or responded to a message. I selected LinkedIn because it provided a medium where I could initiate conversations directly with executives responsible for a corporation's venturing activities. An additional benefit of LinkedIn is it allowed me to drop my geographic boundaries in the United States through which I was able to solicit and receive participation from a geographically diverse group of corporations. 
From this effort, I had 40 corporations participate and complete surveys on ventures. I eliminated one of these companies due to them not meeting the revenue threshold. In total, I collected usable data from 39 corporations and 159 corporate ventures, on average about four ventures per corporation. Of these 159 ventures, 74 were internally generated and 85 were externally acquired. On average, the age of the venture was 6.7 years. The distribution of the companies is shown below in Table 2. Overall response rates were low, but ventures per corporation were good at about 4 per corporation. The 39 corporations had an average revenue of \$4.6B USD (s.d. \$12.8B) and average employees of 8,945 (s.d. 23,690). Using a semi-randomized sample of 50 non-respondents with a similar distribution by country, I compared respondents and nonrespondents. This showed the nonresponding companies to have an average revenue of \$17.2B USD (s.d. \$27.2B USD) and average employees of 51,404 (s.d. 91,334).

While this difference in the size of respondents and non-respondents is uncommon among research in the area (e.g. Covin et al., 2016), it can be explained. While most of the previous data collections into corporate venturing have been into only US firms (e.g. Covin et al., 2016; Klavans es al., 1985), my data set is international and the international corporations had lower average revenue than US firms \$2.6B USD and $\$ 5.9 \mathrm{~B}$ USD, respectively. The average revenue of my data set is very similar to previous research in this area (e.g. Covin et al., 2016) with an average of \$5.5B USD. Also, it is possible that from using the new approach with contacting executives through social media, I was able to have conversations directly with executives from larger corporations. In my experience, I was much more successful at starting conversations with 
international Fortune 1000 level executives using social media rather than calling or attempting emails.

Table 2. Companies that Participated per Country

\begin{tabular}{|c|c|}
\hline The United States of America & 24 \\
\hline Brazil & 6 \\
\hline Italy & 4 \\
\hline Mexico & 2 \\
\hline Dominican Republic & 1 \\
\hline England & 1 \\
\hline France & 1 \\
\hline
\end{tabular}

\section{Data Collection}

Surveys are shown to be the most appropriate means for collecting data pertaining to corporate ventures (Shrader \& Simon, 1997). Data from secondary sources lack the nuances usually needed for detailed analysis of corporate ventures (Shrader \& Simon, 1997). There is no secondary source from which data can be obtained for several of the independent variables I am studying. I used surveys to collect my data for analysis. While scholars have found it useful to hand-deliver surveys when conducting research on CVs (Garrett et al., 2009; Covin et al., 2016), the international scope of this research makes face-to-face interaction with all of the respondents infeasible. Due to this, I utilized Qualtrics to distribute online surveys.

All of the companies identified as potentially engaging CVs in each country were contacted to confirm that they were engaging in CVs and were willing to participate in the study. The online survey is designed so that the participants initially answered whether they are the corporate manager or the venture manager. If the respondent selected corporate manager, they were first asked a set of identifying questions. They were asked to identify the corporation they are at and to name the CV with either the 
actual name or a code name. If a code name was used, the venture manager was later asked to provide this code name. The parent name and CV name was later used to associate the correlating parent and venture data together. The corporate manager was also asked to identify the name and email information of the venture manager so that they could be contacted to complete the venture manager portion of the survey. In the cases of a parent corporation with multiple ventures, the corporate manager was able to complete the survey multiple times to include a survey for each venture.

The corporate manager was asked to complete information about each venture indicating the background information about each venture. They were also asked to answer questions about their perceptions of their company and the venture's corporate culture. Also, they were asked about the turbulence of the marketplace and the absorptive capacity of the parent corporation. It was requested that they also complete questions about the performance of the venture and the extent to which the parent corporation has learned from the venture. The survey contained instructions to the corporate manager that for the purposes of this research they are to consider only businesses that were initially intended to operate as new businesses. They were provided with a figure adapted from Morris et al. (2010) to identify if the venture constituted a new business. See Figure 2. Corporate managers were asked to identify ventures that were both still active and ventures that had been terminated. This research asked corporate managers to consider defunct ventures to avoid skewing the results with survivor bias. Research identifies seven years or less as an appropriate range for identifying new business ventures (McDougall, 1989; Zahra et al. 2000; \& Covin et al., 2016). As such, managers were asked only to consider ventures that were seven years old or less. 
Figure 2: New Business Identification Matrix

\begin{tabular}{|c|c|c|c|c|c|}
\hline & $\begin{array}{l}\text { Market } \\
\text { Creation (New } \\
\text { to "World") }\end{array}$ & $\begin{array}{c}\text { New } \\
\text { Business }\end{array}$ & $\begin{array}{c}\text { New } \\
\text { Business }\end{array}$ & $\begin{array}{c}\text { New } \\
\text { Business }\end{array}$ & $\begin{array}{c}\text { New } \\
\text { Business }\end{array}$ \\
\hline \multirow{4}{*}{$\begin{array}{l}\text { Market Focus } \\
\text { of the Venture }\end{array}$} & $\begin{array}{l}\text { New Market } \\
\text { for the Corp. }\end{array}$ & $\begin{array}{l}\text { Major Market } \\
\text { Development }\end{array}$ & $\begin{array}{c}\text { New } \\
\text { Business }\end{array}$ & $\begin{array}{c}\text { New } \\
\text { Business }\end{array}$ & $\begin{array}{c}\text { New } \\
\text { Business }\end{array}$ \\
\hline & $\begin{array}{l}\text { Extension of } \\
\text { Current Market }\end{array}$ & $\begin{array}{l}\text { Minor Market } \\
\text { Development }\end{array}$ & $\begin{array}{l}\text { Minor Product- } \\
\text { Market } \\
\text { Development }\end{array}$ & $\begin{array}{c}\text { New } \\
\text { Business }\end{array}$ & $\begin{array}{c}\text { New } \\
\text { Business }\end{array}$ \\
\hline & $\begin{array}{l}\text { Current Market } \\
\text { of the Corp. }\end{array}$ & $\begin{array}{c}\text { Market } \\
\text { Penetration }\end{array}$ & $\begin{array}{l}\text { Minor Product } \\
\text { Development }\end{array}$ & $\begin{array}{l}\text { Major Product } \\
\text { Development }\end{array}$ & $\begin{array}{c}\text { New } \\
\text { Business }\end{array}$ \\
\hline & & $\begin{array}{c}\text { Current } \\
\text { Product of the } \\
\text { Corp. }\end{array}$ & $\begin{array}{c}\text { Extension of } \\
\text { Current } \\
\text { Product }\end{array}$ & $\begin{array}{l}\text { New Product } \\
\text { for the Corp. in } \\
\text { Current } \\
\text { Industry }\end{array}$ & $\begin{array}{l}\text { New Product } \\
\text { for the Corp. in } \\
\text { New Industry } \\
\text { (i.e., } \\
\text { Diversification) }\end{array}$ \\
\hline
\end{tabular}

Adapted from Morris, Kuratko, \& Covin (2008).

\section{Independent Variables}

\section{Cultural Distance}

Corporate cultural distance is the measure of how different corporate cultures are.

Cultural distance is often measured using the scale developed by Kogut and Singh (1988) where the scale is used to measure how far removed from a singular culture the other cultures are. This approach could be leading to confounded variables problems where the results are not representative of cultural distance, but are a representation of national cultural effects of the various countries compared to the country of the base culture (Brouthers et al., 2016). As suggested by Brouthers et al. (2016), in this research I use samples of parent corporations from more than two different home countries to overcome 
this confounded variable problem. Another problem with the traditional way of measuring cultural distance is that the subtleties of culture are notoriously difficult to conceptualize and scale (Shenkar, 2001). This is partly due to culture having many different aspects that can each impact the relationship between two firms (Tallman \& Shenkar, 1994). To overcome this, I am using an adapted version of the scale developed by Chatterjee et al. (1992) which measures multiple components of the corporate culture. This instrument contains seven components of corporate culture: 1) innovation and action orientation, 2) risk-taking attitude, 3) lateral independence, 4) top management contact, 5) autonomy and decision-making, 6) performance orientation, and 7) reward orientation. These are determined using a total of twenty-nine questions, each of which is answered using a seven-point Likert scale. Both managers are asked to compare the culture of their company with that of either the parent or CV. A response of " 1 " indicates the two are very similar and a response of " 7 " indicates the two are very different. Culture is composed of many perceptions and nuances that are difficult to measure (Shenkar, 2001). To overcome this, I adapt the instrument to provide a confirming measure of distance. Using the same series of questions, I ask both the parent and CV manager to rate the level of importance of each concept to their company. The questions are measured using a seven-point scale. An answer of " 1 " indicates the respondent strongly agrees that the concept is important and an answer of "7" indicates the respondent strongly disagrees. From these two measures, I calculate cultural distance as the absolute distance between the two responses which should help control for each manager's perceptions of the other company. The full set of questions and the description of the scale is available in the index. 
Cultural distance was collected from both the corporate and venture manager. These two scales were both shown to have strong reliability as they both showed a Cronbach's alpha of 0.97. I then used the six components that loaded heaviest on to the first factor to create a single summated scale for each measure following the recommendations of Aiken \& West (1991). To create the calculated measure for cultural distance, I measured corporate culture of the parent corporation and venture from their respective managers. These scales were both shown to have strong reliability with Cronbach's alpha of 0.94 and 0.93 , respectively. Using the same technique, I then created a summated score for each of the individual companies' culture and found the absolute value difference between the parent and venture to create "calculated cultural distance." Absorptive Capacity

Absorptive capacity is the ability of a firm to utilize external knowledge through the processes of exploratory, transformative, and exploitative learning (Lane et al., 2006). To measure this, I utilize the absorptive capacity scale developed previously by scholars (Lichtenthaler, 2009). The scale is comprised of six total items to measure the three types of learning. The three types of learning are: exploratory, exploitative, and transformative. Each of the three types of learning is divided into two subscales. Exploratory learning is comprised of the ability first to recognize and then assimilate information. Exploitative learning is composed of the ability to both transmute and apply information. Transformative learning is comprised of the ability to both maintain and then reactivate information. The scale is comprised of twenty-five individual questions, all of which are adapted to be answered using a seven-point Likert scale. The questions ask each manager to rate their level of agreement that their company engages in various 
activities where a " 1 " indicates they strongly disagree and a "7" indicates they strongly agree.

Absorptive capacity was measured for both the parent corporation and the venture. These scales were both tested and showed strong reliability with Cronbach's alpha of 0.95 and 0.96, respectively. Then, following the guidance of Aiken and West (1991), I used the six components that loaded the heaviest to the first factor to create summated scores for each of these variables.

\section{Turbulence}

Turbulence for this research is measured as comprehensive environmental turbulence. Environmental turbulence is the rate of change in the composition of the environment (Jaworski \& Kohli, 1993). To capture this, I used an instrument that both measures for turbulence and the competitive intensity of the environment. The turbulence instrument I used was developed through the previous work of scholars (Jaworski \& Kohli, 1993). This scale is comprised of three items: market turbulence, competitive intensity, and technological turbulence. The turbulence scale is comprised of fifteen total questions of which each manager is asked to express their agreement with the statements about the state of the environment using a seven-point Likert scale. A response of " 1 " indicates that the manager strongly disagrees and a response of " 7 " indicates that they strongly agree. This item was collected from the venture manager. In this study, I considered what is the impact of change in turbulences at the venture level, from the CV's industry, and how it impacts perceptions of success. The full set of questions and the description of the scale are available in the Appendix. 
The scale for turbulence showed strong reliability with a Cronbach's alpha score of 0.87. Following the guidance of Aiken and West (1991) I used the six components that loaded the heaviest to the first factor to create summated scores for each of these variables.

Perceived Cultural Distance Congruence

The perceived cultural distance congruence item is a calculated measure. This item is calculated as the absolute distance between the responses of the manager of the parent corporation and the $\mathrm{CV}$ manager to their amount of perceived cultural distance between the two companies. Since culture contains perceptions and nuances (Shenkar, 2001), and since cultural distance is not inherently symmetrical from each company to the other (Shenkar, 2001), this added variable will offer insight into understanding the impact of perceptions about culture and cultural distance. This variable is the calculated absolute value between the summated scores for cultural distance measured from the perspective of both the corporate and venture manager.

\section{Dependent Variables}

\section{Venture Performance}

In this study, venture performance was measured using a multiple question scale. These questions were asked of the corporate manager as s/he had access to the complete financial profile and corporate expectations for the CV. This was measured on a 7-point Likert scale where 1 signaled strongly disagree and 7 signaled strongly agree. The four questions asked about performance were: 1.) The venture generally meets (or met) the expectations of the parent corporation, 2.) The parent corporation views (or viewed) this venture as being successful, overall, 3.) The parent corporation believes (or believed) that 
this venture achieved its key milestones (i.e., events crucial to the venture's successful development) on schedule for each stage of its development, \& 4.) This venture is performing (or performed) well in terms of the criteria (e.g., financial returns, market share, learning/acquisition of new knowledge) the parent corporation considers (or considered) important to the venture's success. If the venture had been terminated, the corporate manager was asked to answer these questions for the venture's final year of operation. This is important due to the understanding that a venture could terminate for reasons other than failure, such as it reached its end goal (Geringer \& Hebert, 1991).

This measure of venture success was measured using the scales developed and used by Kuratko et al., (2009). The utilization of a manager's subjective evaluations of performance has been widely used in research (e.g., Dess \& Robinson, 1984; Covin et al., 1990; Garrett \& Covin, 2015). An advantage of utilizing subjective measures is that it allows us to collect performance data on early-stage ventures even if objective data is not yet available (Dess \& Robinson, 1984). These subjective performance measures were collected from both the corporate manager and the venture manager. Since it is the parent corporation that ultimately decides if the venture will continue operations, the corporate manager's responses were utilized as the dependent variable. Also, even though subjective performance measures gained from managers can be influenced by personality (Zahra et al., 2002) and the individual manager's perceptions (Bantel, 1998), the corporate manager is less likely to be overly biased in overestimating the performance of the CV.

The scale for venture success was tested for reliability and yielded a Cronbach's alpha of 0.95 , indicating strong scale reliability. After testing the reliability using the 
guidance of Aiken and West (1991), I used the four individual components of venture success to create a summated success score.

\section{Control Variables}

I captured and utilized three corporation level controls in my model. The three used were: number of employees, number of ventures, and percentage of sales in largest industry. The number of employees was measured by asking the corporate manager an open-ended question. The average number of employees among the corporations that participated was 12,194 (s.d. 28,622). The number of ventures was measured as the number of ventures the corporation had started in the last seven years. The average response from the participating corporations was 10.7 (s.d. 12.3) ventures. The corporate manager was also asked to identify which percentage of the corporation's total annual sales came from their single largest industry. The average response from the participating corporations was 75.13 (s.d. 22) percentage.

I also captured and utilized six venture-level controls in my model. The six used were: stage of the venture, the number of ventures previously manage by the venture manager, venture age, venture autonomy, operational independence, and learning extensiveness. The stage of the venture was qualified as 1.) Early Stage Venture that has received funding but not yet generated any revenue, 2.) Middle Stage Venture that is generating revenue but is not profitable, or 3.) Established Stage Venture that is currently generating some level of profit. The average of the participating ventures was 1.68 (s.d. 0.83). The venture manager was asked as a measure of experience how many ventures s/he had previously managed not including the current venture. The average among the 
participating managers was 4.9 (s.d. 1.2) ventures. The venture age was collected from the venture manager and I found an average age of 6.6 (s.d. 3.3) years.

Venture autonomy was also collected and utilized as a control from the venture manager. The scale used for venture autonomy was first developed and utilized in Johnson (2012). The construct of venture autonomy was used to measure the extent to which the venture management was responsible for establishing goals, timetables, and internal operations of the venture (Johnson, 2012). This scale consisted of twelve statements to which the venture manager indicated their level of agreement using a seven-point Likert scale. For a full list of the statements, please refer to the appendix. I used Chronbach's alpha to test the reliability of the scale and received a score of 0.93 , indicating the scale had strong reliability. Using the advice of Aiken \& West (1991), I used these multiple components to create a single summated score for analysis. The result of this summated score was an average of 4.46 (s.d. 1.63).

Operations independence was also collected and utilized as a control from the venture manager. The scale used for operations independence was first developed and utilized in Johnson (2012). The construct of operations independence was used to measure to what extent the venture's operations were linked to those of the corporation and its other businesses (Johnson, 2012). This scale consisted of three statements to which the venture manager was asked to express their level of agreement to using a seven-point Likert scale. For a complete list of the statements used, please refer to the appendix. I used Chronbach's alpha to test the reliability of the scale and received a score of 0.89 , indicating that the scale had strong reliability. Using the advice of Aiken and West (1991), I used these multiple components to create a single summated score for 
use in my analysis. The result of this summated score was an average level of independence of 5.25 (s.d. 1.22).

Learning extensiveness of the venture was also collected and utilized as a control variable in the models. The scale used to collect learning extensiveness had previously been utilized in Covin et al., (2018). Learning extensiveness refers to the level to which a venture can obtain and apply valuable knowledge from their corporate parent (Covin et al., 2018). This scale consisted of eleven statements in which the venture manager was asked to what degree their level of knowledge had increased since the start of the venture. They were asked to use a seven-point Likert scale to indicate the amount to which their level of knowledge had increased. For a complete list of the statements and scale used, please refer to the appendix. I used Chronbach's alpha to test the reliability of this scale and received a score of 0.93 , indicating that the scale had strong reliability. I then used the advice of Aiken and West (1991) to consolidate these factors into a single summated score. The result of the summated score was average learning extensiveness of 4.46 (s.d. 1.48).

\section{Analysis Techniques}

The complete research model which includes moderation was analyzed using hierarchical linear modeling (HLM). HLM is appropriate, because of the two levels of the corporate parent and the venture level data. Several of the items used in this study were originally developed using exploratory factor analysis (EFA) to develop constructs (e.g., cultural distance, absorptive capacity, and environmental turbulence). I used confirmatory factor analysis (CFA) to verify that the individual items are reliably loading to the constructs with the sample that I am using. Secondly, I used HLM8 to test the 
moderating hypothesis as well as the complete model. In accordance with the recommendation of Aiken \& West (1991), I tested my moderation hypothesis by centering the variables in the moderation relationship and creating a moderation term through the multiplication of these new centered variables. In addition to collecting the independent and dependent variables described, I also collected control variables not directly related to the model of this dissertation. 


\section{CHAPTER IV: RESULTS}

Tables 3 and 4 below show the descriptive statistics and correlations between the research variables. I present the HLM results in Tables 5-7. Table 5 is the research model using cultural distance measured from the perspective of the corporate manager. Table 6 uses cultural distance from the perspective of the venture manager, and Table 7 is the calculated cultural distance measure. In each of these three tables, I show all four HLM models. Model lincludes all of the control variables. The independent variable of cultural distance is added in model 2. Model 3 then adds each of the moderator variables and finally, Model 4 includes the interaction terms.

I first ran a naïve model in HLM, which is a model that only includes the independent variable. From this naïve model, I was able to obtain sigma squared and tau scores which I then used to calculate the variance explained at both the corporate level, level two, and venture level, level one. Using sigma squared and tau from the HLM naïve model I calculated that $22 \%$ of the variance is explained from corporate-level data, confirming that HLM is the appropriate option for analyzing this data.

I then used HLM to run my full empirical models of the 159 ventures. In each of the three empirical models, Tables 5-7, the HLM analysis showed that one of the control variables, Learning Extensiveness, is positively related with the level of venture success $(\mathrm{p}<.05)$. The three empirical models only showed a statistically significant relationship 
between cultural distance and venture success when cultural distance was measured from the perspective of the venture manager, Table 6 .

\begin{tabular}{|c|c|c|c|}
\hline \multicolumn{4}{|c|}{ Table 3.} \\
\hline \multicolumn{4}{|c|}{ Descriptive Statistics } \\
\hline Variables & Mean & $\begin{array}{c}\text { Std. } \\
\text { Deviation }\end{array}$ & $\alpha$ \\
\hline 1 Venture Success & 5.41 & 1.45 & 0.95 \\
\hline $\begin{array}{l}2 \text { Cultural Distance } \\
\text { (corporate manager) }\end{array}$ & 2.84 & 1.76 & 0.97 \\
\hline $\begin{array}{l}3 \text { Cultural Distance } \\
\text { (venture manager) }\end{array}$ & 3.08 & 1.59 & 0.97 \\
\hline $\begin{array}{l}\text { 4 Cultural Distance } \\
\text { (calculated) }\end{array}$ & 1.14 & 0.98 & n.a. \\
\hline $\begin{array}{c}5 \text { Absorptive Cabacity } \\
\text { (venture) }\end{array}$ & 4.82 & 1.33 & 0.96 \\
\hline 6 Turbulence & 4.28 & 1.19 & 0.87 \\
\hline 7 Congruence & 1.16 & 1.30 & n.a. \\
\hline $\begin{array}{l}8 \text { Employees of } \\
\text { Corporation* }\end{array}$ & $12,193.89$ & $28,622.04$ & n.a. \\
\hline $\begin{array}{l}9 \# \text { of Ventures Started } \\
\text { in the last } 7 \text { years* }\end{array}$ & 10.68 & 12.28 & n.a. \\
\hline $\begin{array}{l}10 \text { Corporate } \% \text { of } \\
\text { revenue from largest } \\
\text { industry* }\end{array}$ & 75.13 & 22.00 & n.a. \\
\hline 11 Stage of the Venture & 1.68 & 0.83 & n.a. \\
\hline $\begin{array}{c}12 \# \text { of ventures } \\
\text { previously managed }\end{array}$ & 4.88 & 1.19 & n.a. \\
\hline $\begin{array}{c}13 \text { Venture Age (in } \\
\text { years) }\end{array}$ & 6.64 & 3.27 & n.a. \\
\hline 14 Venture Autonomy & 4.46 & 1.63 & 0.93 \\
\hline $\begin{array}{c}15 \text { Operational } \\
\text { Independence of Venture }\end{array}$ & 5.25 & 1.22 & 0.89 \\
\hline $\begin{array}{c}16 \text { Learning } \\
\text { Extensiveness of } \\
\text { Venture Mgr } \\
\end{array}$ & 4.46 & 1.48 & 0.93 \\
\hline $\begin{array}{l}\text { * These variables are me } \\
\text { (vs. } 159 \text { for the other v }\end{array}$ & $\begin{array}{l}\text { ured at the } \\
\text { iables whic } \\
\text { level). }\end{array}$ & $\begin{array}{l}\text { orate parent } \\
\text { e measured a }\end{array}$ & $\begin{array}{l}\text { so } \mathrm{N}=37 \\
\text { venture }\end{array}$ \\
\hline
\end{tabular}




\begin{tabular}{|c|c|c|c|c|c|c|c|c|c|c|c|c|c|c|c|}
\hline 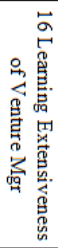 & 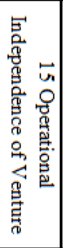 & 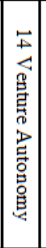 & 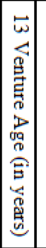 & 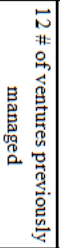 & 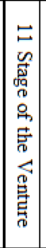 & 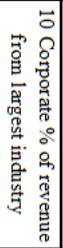 & 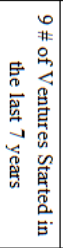 & 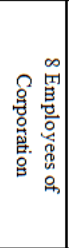 & 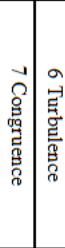 & 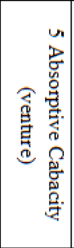 & 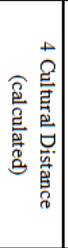 & 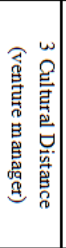 & 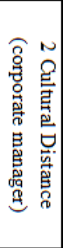 & 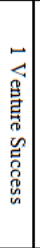 & \\
\hline ஃ̊ & 웅 & : & ì & $\dot{0}$ & $\begin{array}{l}0 \\
\text { in } \\
0\end{array}$ & 宫 & : & ì & \begin{tabular}{l|l} 
\\
ì
\end{tabular} & $\stackrel{\circ}{+}$ & $\begin{array}{l}\dot{b} \\
\dot{a}\end{array}$ & $\begin{array}{l}\dot{0} \\
\dot{i}\end{array}$ & ì & $\overrightarrow{8}$ & - \\
\hline ¿ & ì & $\begin{array}{l}0 \\
\vdots \\
\end{array}$ & : & $\dot{0}$ & 입 & : & i & $\dot{\zeta}_{+}$ & $\begin{array}{l} \\
\dot{\infty}\end{array}$ & ì & : & 足 & $\overrightarrow{8}$ & & $N$ \\
\hline 웅 & i্ & 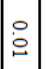 & 잉 & $\dot{0}$ & $\because$ & $\stackrel{\circ}{\exists}$ & 웅 & 움 & 엄요 & i. & $\begin{array}{l}\text { 足 } \\
\text { 品 }\end{array}$ & $\overrightarrow{8}$ & & & | \\
\hline : & b & 입 & $\stackrel{0}{\circ}$ & : & 이 & $\stackrel{\circ}{\stackrel{5}{+}}$ & i & 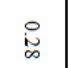 & $\begin{array}{l}\circ \\
\vdots\end{array}$ & : & $\overrightarrow{8}$ & & & & + \\
\hline 옿 & 웅 & : & ì & ஜ & $\mid \begin{array}{l}\dot{0} \\
\dot{i}\end{array}$ & $\dot{5}$ & ì & $\dot{~}$ & \begin{tabular}{l|l}
$\dot{b}$ \\
$\dot{b}$
\end{tabular} & $\overrightarrow{8}$ & & & & & יטי \\
\hline i & : & . & : & 항 & 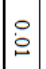 & $\dot{b}$ & $\dot{b}$ & 衣 & $\dot{\circ}$ & & & & & & $a$ \\
\hline bे & $\dot{\square}$ & 임 & 웅 & 용 & : & $\dot{\grave{\partial}}$ & 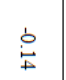 & $\dot{\circ}$ & $\overrightarrow{8}$ & & & & & & \\
\hline$\dot{\dot{\omega}}$ & ì & 官 & 잉 & 㲾 & $\begin{array}{l}1 \\
0 \\
0 \\
ن\end{array}$ & 总 & : & 8 & & & & & & & \\
\hline 豈 & 它 & $\begin{array}{l}\dot{0} \\
\text { 品 }\end{array}$ & 인 & 옴 & \begin{tabular}{|l|}
$\dot{1}$ \\
$\dot{+}$
\end{tabular} & 㟧 & $\overrightarrow{8}$ & & & & & & & & 0 \\
\hline : & ì & \begin{tabular}{|l|} 
\\
in \\
o
\end{tabular} & 웅 & 응 & \begin{tabular}{|l|} 
\\
$\vdots$ \\
2
\end{tabular} & $\overrightarrow{8}$ & & & & & & & & & $\overrightarrow{0}$ \\
\hline$\stackrel{\circ}{\circ}$ & : & $\begin{array}{l}0 \\
\text { in }\end{array}$ & $\mid \begin{array}{l}0 \\
\text { 品 }\end{array}$ & $\underset{\infty}{\stackrel{\circ}{\infty}}$ & $\vec{\circ}$ & & & & & & & & & & Е \\
\hline$\stackrel{\dot{\Xi}}{\vec{y}}$ & $\dot{\grave{g}}$ & \begin{tabular}{|c|}
0 \\
$\vdots$ \\
\end{tabular} & $\therefore$ & & & & & & & & & & & & $\vec{i}$ \\
\hline ì & 훙 & $\begin{array}{l}0 \\
0 \\
0\end{array}$ & $\overrightarrow{8}$ & & & & & & & & & & & & $\vec{\omega}$ \\
\hline 움 & 总 & $\overrightarrow{8}$ & & & & & & & & & & & & & $\mp$ \\
\hline 耐 & $\dot{8}$ & & & & & & & & & & & & & & $\vec{n}$ \\
\hline 8 & & & & & & & & & & & & & & & 'बे] \\
\hline
\end{tabular}




\begin{tabular}{|c|c|c|c|c|}
\hline \multicolumn{5}{|c|}{ Table 5.} \\
\hline \multicolumn{5}{|c|}{ Results of Hierarchical Linear Modeling CDCM } \\
\hline \multicolumn{5}{|c|}{ DV is Venture Success } \\
\hline Variable & Model 1 & Model 2 & Model 3 & Model 4 \\
\hline \multirow[t]{2}{*}{ Intercept } & $5.39 * * *$ & $5.39 * * *$ & $5.40 * * *$ & $5.40 * * *$ \\
\hline & $(0.16)$ & $(0.16)$ & $(0.16)$ & $(0.16)$ \\
\hline \multicolumn{5}{|l|}{ Controls } \\
\hline \multirow[t]{2}{*}{ Number of Employees } & -0.00 & -0.00 & -0.00 & -0.00 \\
\hline & $(0.00)$ & $(0.00)$ & $(0.00)$ & $(0.00)$ \\
\hline \multirow[t]{2}{*}{ Number of Ventures } & 0.01 & 0.01 & 0.01 & 0.01 \\
\hline & $(0.02)$ & $(0.02)$ & $(0.02)$ & $(0.02)$ \\
\hline \multirow{2}{*}{$\begin{array}{l}\text { Percentage in largest } \\
\text { industry }\end{array}$} & -0.00 & -0.00 & -0.00 & -0.00 \\
\hline & $(0.01)$ & $(0.01)$ & $(0.01)$ & $(0.01)$ \\
\hline \multirow[t]{2}{*}{ Stage of the Venture } & -0.11 & -0.01 & -0.25 & -0.26 \\
\hline & $(0.18)$ & $(0.24)$ & $(0.18)$ & $(0.17)$ \\
\hline \multirow{2}{*}{$\begin{array}{l}\text { Number of previously } \\
\text { managed ventures }\end{array}$} & -0.16 & -0.16 & -0.08 & -0.08 \\
\hline & $(0.10)$ & $(0.10)$ & $(0.07)$ & $(0.07)$ \\
\hline \multirow[t]{2}{*}{ Venture Age (in years) } & 0.05 & 0.05 & $0.06+$ & $0.07^{*}$ \\
\hline & $(0.03)$ & $(0.03)$ & $(0.03)$ & $(0.03)$ \\
\hline \multirow[t]{2}{*}{ Venture Autonomy } & 0.05 & 0.08 & 0.08 & 0.08 \\
\hline & $(0.19)$ & $(0.17)$ & $(0.16)$ & $(0.16)$ \\
\hline \multirow[t]{2}{*}{ Operations Independence } & 0.08 & 0.07 & 0.05 & 0.02 \\
\hline & $(0.12)$ & $(0.11)$ & $(0.09)$ & $(0.08)$ \\
\hline \multirow[t]{2}{*}{ Learning Extensiveness } & $0.27^{*}$ & $0.27^{*}$ & $0.14^{*}$ & $0.14^{*}$ \\
\hline & $(0.13)$ & $(0.13)$ & $(0.07)$ & $(0.07)$ \\
\hline \multicolumn{5}{|l|}{ Main effect } \\
\hline \multirow{2}{*}{$\begin{array}{l}\text { Cultural Distance (from } \\
\text { Corporate manager) }\end{array}$} & & -0.24 & -0.10 & -0.17 \\
\hline & & $(0.19)$ & $(0.13)$ & $(0.11)$ \\
\hline \multicolumn{5}{|l|}{ Moderators } \\
\hline \multirow[t]{2}{*}{ Absorptive Capacity } & & & -0.24 & -0.23 \\
\hline & & & $(0.18)$ & $(0.17)$ \\
\hline \multirow[t]{2}{*}{ Turbulence } & & & -0.02 & -0.01 \\
\hline & & & $(0.08)$ & $(0.08)$ \\
\hline \multirow[t]{2}{*}{ Congruence } & & & $-0.65 * * *$ & $-0.62 * * *$ \\
\hline & & & $(0.14)$ & $(0.15)$ \\
\hline \multicolumn{5}{|l|}{ Interaction Terms } \\
\hline \multirow[t]{2}{*}{ CDCM $\times$ ACAPV } & & & & -0.06 \\
\hline & & & & $(0.10)$ \\
\hline \multirow[t]{2}{*}{ CDCM x TBV } & & & & 0.06 \\
\hline & & & & $(0.04)$ \\
\hline \multirow[t]{2}{*}{ CDCM x CONG } & & & & 0.05 \\
\hline & & & & $(0.06)$ \\
\hline \multicolumn{5}{|c|}{$\begin{array}{l}\text { Final estimation of fixed effects (with robust standard errors in parenthesis) are } \\
\text { reported }+\mathrm{p}<.1 ;{ }^{*} p<.05 ; *{ }^{*} p .01 ; * * * \mathrm{p}<.001\end{array}$} \\
\hline
\end{tabular}




\begin{tabular}{|c|c|c|c|c|}
\hline \multicolumn{5}{|c|}{ Table 6.} \\
\hline \multicolumn{5}{|c|}{ Results of Hierarchical Linear Modeling CDVM } \\
\hline \multicolumn{5}{|c|}{ DV is Venture Success } \\
\hline Variable & Model 1 & Model 2 & Model 3 & Model 4 \\
\hline \multirow[t]{2}{*}{ Intercept } & $5.39 * * *$ & $5.39 * * *$ & $5.40 * * *$ & $5.40 * * *$ \\
\hline & $(0.16)$ & $(0.16)$ & $(0.16)$ & $(0.16)$ \\
\hline \multicolumn{5}{|l|}{ Controls } \\
\hline \multirow[t]{2}{*}{ Number of Employees } & -0.00 & -0.00 & -0.00 & -0.00 \\
\hline & $(0.00)$ & $(0.00)$ & $(0.00)$ & $(0.00)$ \\
\hline \multirow[t]{2}{*}{ Number of Ventures } & 0.01 & 0.01 & 0.00 & 0.00 \\
\hline & $(0.02)$ & $(0.02)$ & $(0.02)$ & $(0.02)$ \\
\hline \multirow{2}{*}{$\begin{array}{l}\text { Percentage in largest } \\
\text { industry }\end{array}$} & -0.00 & -0.00 & -0.00 & -0.00 \\
\hline & $(0.01)$ & $(0.01)$ & $(0.01)$ & $(0.01)$ \\
\hline \multirow[t]{2}{*}{ Stage of the Venture } & -0.11 & -0.06 & $-0.27+$ & -0.24 \\
\hline & $(0.18)$ & $(0.17)$ & $(0.14)$ & $(0.17)$ \\
\hline \multirow{2}{*}{$\begin{array}{l}\text { Number of previously } \\
\text { managed ventures }\end{array}$} & -0.16 & -0.15 & -0.08 & -0.04 \\
\hline & $(0.10)$ & $(0.09)$ & $(0.08)$ & $(0.07)$ \\
\hline \multirow[t]{2}{*}{ Venture Age (in years) } & 0.05 & 0.04 & $0.07+$ & $0.07^{*}$ \\
\hline & $(0.03)$ & $(0.03)$ & $(0.03)$ & $(0.03)$ \\
\hline \multirow[t]{2}{*}{ Venture Autonomy } & 0.05 & 0.01 & 0.06 & 0.05 \\
\hline & $(0.19)$ & $(0.17)$ & $(0.15)$ & $(0.11)$ \\
\hline \multirow{2}{*}{\begin{tabular}{|l} 
Operations \\
Independence
\end{tabular}} & 0.08 & 0.03 & 0.02 & -0.00 \\
\hline & $(0.12)$ & $(0.11)$ & $(0.08)$ & $(0.09)$ \\
\hline \multirow[t]{2}{*}{ Learning Extensiveness } & $0.27 *$ & $0.26 *$ & $0.14^{*}$ & $0.18 * *$ \\
\hline & $(0.13)$ & $(0.11)$ & $(0.07)$ & $(0.07)$ \\
\hline \multicolumn{5}{|l|}{ Main effect } \\
\hline \multirow{2}{*}{$\begin{array}{l}\text { Cultural Distance (from } \\
\text { Venture manager) }\end{array}$} & & $-0.33^{*}$ & -0.16 & $-0.20^{*}$ \\
\hline & & $(0.13)$ & $(0.11)$ & $(0.08)$ \\
\hline \multicolumn{5}{|l|}{ Moderators } \\
\hline \multirow[t]{2}{*}{ Absorptive Capacity } & & & -0.28 & $-0.46^{*}$ \\
\hline & & & $(0.20)$ & $(0.18)$ \\
\hline \multirow[t]{2}{*}{ Turbulence } & & & -0.02 & -0.02 \\
\hline & & & $(0.07)$ & $(0.07)$ \\
\hline \multirow[t]{2}{*}{ Congruence } & & & $-0.62 * * *$ & $-0.60 * * *$ \\
\hline & & & $(0.16)$ & $(0.13)$ \\
\hline \multicolumn{5}{|l|}{ Interaction Terms } \\
\hline \multirow[t]{2}{*}{ CDVM x ACAPV } & & & & $0.26 * * *$ \\
\hline & & & & $(0.08)$ \\
\hline \multirow[t]{2}{*}{ CDVM x TBV } & & & & 0.01 \\
\hline & & & & $(0.04)$ \\
\hline \multirow[t]{2}{*}{ CDVM x CONG } & & & & 0.08 \\
\hline & & & & $(0.06)$ \\
\hline \multicolumn{5}{|c|}{$\begin{array}{l}\text { Final estimation of fix ed effects (with robust standard errors in parenthesis) } \\
\text { are reported }+\mathrm{p}<.1 ; * \mathrm{p}<.05 ; * \mathrm{p}<.01 ; * * * \mathrm{p}<.001\end{array}$} \\
\hline
\end{tabular}




\begin{tabular}{|c|c|c|c|c|}
\hline \multicolumn{5}{|c|}{ Table 7.} \\
\hline \multicolumn{5}{|c|}{ Results of Hierarchical Linear Modeling CDCAL } \\
\hline \multicolumn{5}{|c|}{ DV is Venture Success } \\
\hline Variable & Model 1 & Model 2 & Model 3 & Model 4 \\
\hline \multirow[t]{2}{*}{ Intercept } & $5.39 * * *$ & $5.39 * * *$ & $5.40 * * *$ & $5.40 * * *$ \\
\hline & $(0.16)$ & $(0.16)$ & $(0.16)$ & $(0.16)$ \\
\hline \multicolumn{5}{|l|}{ Controls } \\
\hline \multirow[t]{2}{*}{ Number of Employees } & -0.00 & -0.00 & -0.00 & -0.00 \\
\hline & $(0.00)$ & $(0.00)$ & $(0.00)$ & $(0.00)$ \\
\hline \multirow[t]{2}{*}{ Number of Ventures } & 0.01 & 0.01 & 0.01 & 0.00 \\
\hline & $(0.02)$ & $(0.02)$ & $(0.02)$ & $(0.02)$ \\
\hline \multirow{2}{*}{$\begin{array}{l}\text { Percentage in largest } \\
\text { industry }\end{array}$} & -0.00 & -0.00 & -0.00 & -0.00 \\
\hline & $(0.01)$ & $(0.01)$ & (0.01) & $(0.01)$ \\
\hline \multirow[t]{2}{*}{ Stage of the Venture } & -0.11 & -0.11 & $-0.30+$ & $-0.28+$ \\
\hline & $(0.18)$ & $(0.18)$ & $(0.17)$ & $(0.17)$ \\
\hline \multirow{2}{*}{$\begin{array}{l}\text { Number of previously } \\
\text { managed ventures }\end{array}$} & -0.16 & $-0.16+$ & -0.10 & -0.11 \\
\hline & $(0.10)$ & $(0.10)$ & $(0.07)$ & $(0.09)$ \\
\hline \multirow[t]{2}{*}{ Venture Age (in years) } & 0.05 & 0.05 & $0.07^{*}$ & $0.06^{*}$ \\
\hline & $(0.03)$ & $(0.03)$ & $(0.03)$ & $(0.03)$ \\
\hline \multirow[t]{2}{*}{ Venture Autonomy } & 0.05 & 0.05 & 0.07 & 0.06 \\
\hline & $(0.19)$ & $(0.19)$ & $(0.16)$ & $(0.16)$ \\
\hline \multirow{2}{*}{$\begin{array}{l}\text { Operations } \\
\text { Independence }\end{array}$} & 0.08 & 0.08 & 0.06 & 0.06 \\
\hline & $(0.12)$ & $(0.12)$ & $(0.09)$ & $(0.09)$ \\
\hline \multirow[t]{2}{*}{ Learning Extensiveness } & $0.27^{*}$ & $0.27^{*}$ & $0.14+$ & $0.14+$ \\
\hline & $(0.13)$ & $(0.13)$ & $(0.08)$ & $(0.08)$ \\
\hline \multicolumn{5}{|l|}{ Main effect } \\
\hline \multirow{2}{*}{$\begin{array}{l}\text { Cultural Distance } \\
\text { (Calculated) }\end{array}$} & & 0.01 & 0.13 & 0.11 \\
\hline & & $(0.15)$ & $(0.15)$ & $(0.12)$ \\
\hline \multicolumn{5}{|l|}{ Moderators } \\
\hline \multirow[t]{2}{*}{ Absorptive Capacity } & & & -0.24 & -0.25 \\
\hline & & & $(0.20)$ & $(0.18)$ \\
\hline \multirow[t]{2}{*}{ Turbulence } & & & -0.03 & -0.03 \\
\hline & & & $(0.06)$ & $(0.06)$ \\
\hline \multirow[t]{2}{*}{ Congruence } & & & $-0.68 * * *$ & $-0.68 * * *$ \\
\hline & & & $(0.14)$ & $(0.15)$ \\
\hline \multicolumn{5}{|l|}{ Interaction Terms } \\
\hline \multirow[t]{2}{*}{ CDCAL $\times$ ACAPV } & & & & -0.01 \\
\hline & & & & $(0.11)$ \\
\hline \multirow[t]{2}{*}{ CDCAL x TBV } & & & & 0.03 \\
\hline & & & & $(0.06)$ \\
\hline \multirow[t]{2}{*}{ CDCAL x CONG } & & & & 0.03 \\
\hline & & & & $(0.18)$ \\
\hline \multicolumn{5}{|c|}{$\begin{array}{c}\text { Final estimation of fixed effects (with robust standard errors in parenthesis) } \\
\text { are reported }+\mathrm{p}<.1 ; * \mathrm{p}<.05 ; * \mathrm{p}<.01 ; * * \mathrm{p}<.001\end{array}$} \\
\hline
\end{tabular}


Table 6 shows that when measuring cultural distance from the perspective of the venture manager, there is a main effect and that an increase in cultural distance is negatively related with the level of venture success $(\mathrm{p}<.05)$. All three empirical models, Tables 5-7, show that regardless of the manner of measuring cultural distance, one of the proposed moderators had a direct effect, congruence between the corporate and venture managers' perceptions of cultural distance. This showed that an increase in a lack of congruence between the perceptions of the two managers is negatively related to venture success $(\mathrm{p}<.001)$. The empirical model using cultural distance measured from the venture manager, Table 6 , shows statistically significant interaction effects. Table 6 shows that when using cultural distance measured from the perspective of the venture manager shows that the absorptive capacity of the venture positively moderates the relationship between cultural distance and venture success $(\mathrm{p}<.001)$.

Cultural distance was measured in three separate manners for this research: from the perspective of the corporate manager, from the perspective of the venture manager, and a calculated score based on the two manager's perceptions of their own company's culture. I used these three separate measures to run my three separate sets of HLM models and test my various sets of hypotheses. Of the three manners of measuring cultural distance, the measure from the perspective of the venture manager was the only one to be statistically significant at the $\mathrm{p}<.1$ level. This only showed support for Hypothesis $1 \mathrm{~b}$ from my first set of hypotheses. The complete results of which hypotheses were supported or not supported can be seen in Table 8 . The hypotheses that were supported showed support that an increase in cultural distance from the perspective of the venture manager negatively impacted venture success. The research also found 
support for Hypothesis 2b. Support for this hypothesis supported that an increase in the absorptive capacity of the venture positively moderated the impact of cultural distance on the success of the venture.

\begin{tabular}{|c|c|}
\hline \multicolumn{2}{|c|}{ Table 8. } \\
\hline \multicolumn{2}{|c|}{ Hypotheses Results } \\
\hline Hypothesis & Supported or Not \\
\hline 1a. & Not Supported \\
\hline 1b. & Supported* \\
\hline 1c. & Not Supported \\
\hline 2a. & Supported*** \\
\hline 2b. & Not Supported \\
\hline 2c. & Not Supported \\
\hline 3a. & Not Supported \\
\hline 3b. & Not Supported \\
\hline 3c. & Not Supported \\
\hline 4a. & Not Supported \\
\hline 4b. & 4c. \\
\hline \multicolumn{2}{|c|}{} \\
Final estimation of fixed effects (with robust standard errors \\
in parenthesis) are reported +p<.1; *p<.05;**p<.01; \\
***p $<.001$ \\
\hline
\end{tabular}

I tested for the potential of endogeneity using instrumental variables. I chose these instrumental variables using the criteria that they not be correlated with my research model's dependent variable. I chose "parent-venture similarity" and "top management support of the venture". While some authors prefer to use different software packages and specific statistical tests for testing endogeneity (i.e. Stata and the Wu-Hausman test), these were not the most appropriate for my data. HLM is a statistical modeling technique that can account for variation at multiple levels and is appropriate to use when working with nested data (Raudenbush \& Bryk, 2002). Fortunately, there is an analysis technique developed my Semadeni et al., (2014) that allows for testing for endogeneity while using 
HLM. I used the two-stage analytical approach recommended by Semadeni et al., (2014) with my data to test for endogeneity. I used SPSS to run simple regressions with my instrumental variables and regress these on the dependent variable. From these simple regression models, I saved the residuals as new variables. I then added these new variables to my HLM models. The addition of this new variable did not significantly impact any of the hypothesized effects. Since the addition of this variable in essence left the research model unchanged it suggests that endogeneity is not a problem in my models.

Due to the nature of the data, having very large standard deviations among size measures of the participating corporation, I was concerned that heterogeneity of the data may be impacting my results. A common test for heterogeneity is to remove the outliers and then run the model without outliers. To test this, I followed the advice of Howell et al. (1998) by removing corporations from the data set further than three standard deviations from the mean revenue of corporations. With my data, the large standard deviation created a problem. Because the standard deviation was larger than the mean, this process only resulted in removing one corporation from consideration. The results of running the model without this one corporation had no significant changes.

Heterogeneity of error variance can be a large problem in data analysis if variances are a result of level 1 or level 2 variables and are not random (Raudenbush \& Byrk, 2002). Luckily in HLM 7 and above, it is possible to test for these problems by running the variance-covariance components test of level 2 variables and homogeneity of level 1 variables (Garson, 2013). Following the advice of Raudenbush \& Byrk (2002), I was able to see if heterogeneity in the data was significantly impacting my results. To do 
this, I first obtained the deviance from my base HLM model. I then added this into the model of hypothesis testing and set the model to test for homogeneity. The variancecovariance components test yielded a p-value of greater than 0.500 . This result signals that level 2 covariance reduced deviance by a non-significant amount (Garson, 2013). The results of the homogeneity test yielded a p-value of greater than 0.500 . This tested the assumption that when the model is run for each of the 159 ventures, they have homogenous residual variance (Garson, 2013). The result of this test was a nonsignificant $\mathrm{p}$-value, which indicates heterogeneity in the data is not a problem (Raudenbush \& Byrk, 2002). 


\section{CHAPTER V: DISCUSSION}

The implications of this research are a contribution in the already established but underdeveloped theory of parenting advantage. The parenting advantage literature shows that a venture can perform better by having a particular corporate parent than any other corporate parent (Campbell et al., 1995). What the parenting advantage doesn't consider is that this may be a more complex issue than just if a corporate parent has beneficial or complementary resources or assets for their venture. There could be underlying factors that strain this parental relationship and inhibit the parent corporation from sufficiently nurturing their venture and transferring the parenting advantage to them. This concept has gained support in research of human parents and their offspring as cultural distance between parents and children has shown negative outcomes in the children (Tseng \& Fuligni, 2000). This research found evidence that an increase in the amount cultural distance between a corporate parent and their CV leads to a decrease in the success of the respective $\mathrm{CV}$. This implies that venture success is not purely a function of how well the products, markets, or technologies of the parent and venture mesh together. The parenting relationship between a corporation and its ventures is more complex than originally thought and is impacted by the amount of distance from the other company. The increase in distance may be straining the relationship between the two companies, thereby inhibiting the extent to which a parent can transfer any parenting advantage they may have to their offspring. 
Cultural distance is one of the most popular constructs in international business research (Shenkar, 2012). While CVs are used as vehicles through which corporations can enter new international markets (i.e. Birkinshaw, 1997; Callaway, 2008) until this point it had not been included in CV literature. Cultural distance measured from the perspective of the venture manager was shown to be the most statistically significant of the three measures of distance. This implies that the venture and its employees, represented by the opinions of the venture manager, could be most sensitive to feeling a sense of "distance" or "isolation" from the parent corporation. Shenkar (2001) found that an increase in cultural distance can create a "drag" that results in more difficult communications and a poorer quality relationship. I found support that when the venture manager perceives there is a greater amount of cultural distance between the parent and venture there is indeed a decrease in the success of the venture. This finding could lead to lead to a method for improving CV success. It is possible, as I have demonstrated, to learn about the perceptions of culture that the $\mathrm{CV}$ and corporate managers have. This data can be collected by corporations and then used not only to analyze and better understand the relationship between the two managers but also to coach the managers about these perceptions and how to work through them. This could provide corporations a method through which to improve relationships and CV performance before a CV fails.

I devised a calculated measure for cultural distance that was calculated with the intent to avoid any biases or prejudices of the venture and corporate manager. This measure was not shown to have a statistically significant impact on venture success. This supports the assertion by Shenkar (2001) that there is no reason to assume symmetry in cultural distance. The calculated measure of cultural distance assumes symmetry in the 
relationship and was not found to have a statistically significant relationship. This implies that it is not so much a pure measure of cultural distance that creates friction as it is the perceptions of distance by the managers. In practice, this could lead to a change in the way corporations communicate and deal with their ventures. Corporations need to improve their ability to communicate effectively with and nurture the ventures that they start. There needs to be a certain amount of understanding or compassion for these newly started or acquired businesses. While ventures are asked to operate, sometimes physically or culturally far from the parent corporation, they need to clearly understand the goals and purposes of the venture and have this communicated to them clearly from the parent. The parent needs to communicate not only how the venture will be measured in matters of success, but also how the venture will be operating and the venture's role with the parent corporation.

Although the corporate manager has the obligation to understand the culture of a venture is different and make its managers feel like they are understood, the venture manager in turn has the obligation to understand the venture is culturally different and interact as harmoniously as possible with the parent corporation. Understanding that there is often an amount of cultural distance between the two companies should lead the managers to be more understanding while engaging in interactions between the two distant companies. This distance may manifest itself in both unique processes, mental and physical, and jargon for describing these activities. A distant culture in this way without the proper level of understanding could function in the same way as having conversations in multiple languages. An increase in understanding distance exists and 
the languages are not the same should lead to more patience and both sides articulating their respective points in a manner more concise.

Scholars have noted a failure within CV research to include multiple sources of data and align with major theoretical streams (Ireland \& Webb, 2007; Hill \& Gorgoulas, 2016). This research used multiple scales from major theoretical streams that contained multiple components as part of the survey that was distributed. Three of these types of scales absorptive capacity, turbulence, and corporate culture had interesting loadings. While each of the components could be separated out and showed strong scale validity and the scales naturally load onto the same number of components, there was usually comingling in one primary factor that had the heaviest loadings. This could indicate that, at least with this data set, these traits are simultaneously manifesting across the various subdimensions. This should lead to further exploration into these scales as it may be possible in the setting of large corporations, they will frequently manifest themselves in this way and not as scales with multiple clear components.

Scholars have previously found that there is no correlation between the number of CVs a corporation has previously started and the amount of success each venture achieves (Kuratko et al., 2009). This research provides many insights and directions for potential future research, as it implies the relationship between the two liaisons could be very influential on the amount of success a new venture achieves. Although not part of the model, I found support for a relationship between both learning extensiveness and congruence between the managers' perceptions of corporate culture and venture success. Congruence is a calculated measure of the distance between the corporate and venture managers' responses to cultural distance. This relationship is very difficult to collect 
primary data on, especially dyadic data from both companies. This rare glimpse into this relationship indicates a need to explore further the intricacies of this relationship and explore further how the level of agreement, or the two managers being on the same page, impacts their relationship and eventual success of the venture. I believe this is a very interesting point to explore further as it relates to the perceptions of culture more than a pure distance of culture. This is particularly interesting because while the distance between a parent and its venture is unavoidable, feelings of distance can be changed through changes in the way the two management teams interact with each other.

Also, while this model analyzes an international data set with ventures from multiple countries, it does not control for any impact national culture may have on the relationship. I believe there is an opportunity to explore the relationship between national cultural and corporate culture in the future with this data set. In the context of international corporations there is an opportunity to investigate how strongly national culture can moderate the corporate culture of an international firm entering that market. The ability of a corporation to adapt to a new national culture could impact the amount of success the corporation can obtain in this new culture, assuming it is different than the culture of its' home country.

As with any research, this study is not immune to having limitations. While this is an international data set, it does not include every country or region. I was unable to include any Asian or African corporations or ventures, for example. While my research applies to the western world as it includes ventures from Canada through South America, it may lack applicability in far eastern cultures where I was unable to gain data. 
It also appears, based on the similarity in the size of corporations between my study and former studies in the area (e.g. Covin et al., 2016) that there is a natural selection bias of certain size corporations to participate. In my experience, the largest corporations, while involved in corporate venturing were more worried about protecting data and privacy than participating and potentially learning from research. Also, smaller corporations that may be interested in or participating in venturing activities didn't qualify to participate in this type of research. While this research should be representative of the average corporation involved in corporate venturing, it may not be applicable to either the largest or smallest corporations involved in corporate venturing as they may face a unique set of challenges uncommon in the majority of venturing corporations.

While my response rates per country were low this seems to be a recurring problem in this research. In part, because it is difficult to identify and/or obtain primary data from corporations involved in corporate venturing a large part of the body of research of the field is qualitative (Garrett, 2010). The majority of the few data collections into corporate venturing (i.e. Burgers et al., 2009; Covin \& Garrett 2009) only collected data in their respective home countries. This collection of primary data marks one of the first attempts to collect an international primary data set into corporate venturing. While per country response rates are low, this collection does include a comparable number to total ventures to previous research. In an effort to normalize the data I did use the same criteria to include corporations involved in corporate venturing in every country. 
In conclusion, this research has the potential to make both theoretical and practical contirbutions, because my findings show support for the proposition that the perceptions of culture impact the success of a corporate venture. While it may be difficult to change perceptions, changing these perceptions could finally lead to higher success rates among corporate ventures. While facing limitations, this research is widely applicable as it includes corporations and ventures from various countries and of a wide range of sizes. This research should provide a basis to expand this field of research to more carefully understand and improve the relationship between management of parent corporations and their ventures. This research shows this rarely explored relationship is deserving of more efforts as it impacts the amount of success a venture can have. Also, since this is a relationship it is something that can be improved through altering the actions of the various actors to better maintain levels of harmonious homeostasis. 


\section{REFERENCES}

Adams, R. M. (1969). An approach to new business ventures. Research Management, 12(4), 255-260.

Aiken, L. S., West, S. G., \& Reno, R. R. (1991). Multiple regression: Testing and interpreting interactions. Sage.

Bantel, K. A. (1998). Technology-based,“adolescent” firm configurations: Strategy identification, context, and performance. Journal of Business Venturing, 13(3), 205-230.

Biggadike, E. R. (1979). Corporate diversification: Entry, strategy, and performance, 205. Division of Research, Graduate School of Business Administration, Harvard University; Cambridge, MA.

Birkinshaw, J. (1997). Entrepreneurship in multinational corporations: The characteristics of subsidiary initiatives. Strategic management journal, 18(3), 207-229.

Björkman, I., Stahl, G. K., \& Vaara, E. (2007). Cultural differences and capability transfer in cross-border acquisitions: The mediating roles of capability complementarity, absorptive capacity, and social integration. Journal of International Business Studies, 38(4), 658-672.

Black, J. S., \& Mendenhall, M. (1991). The U-curve adjustment hypothesis revisited: A review and theoretical framework. Journal of International Business Studies, 22(2), 225-247. 
Brouthers, K. D., Geisser, K. D., \& Rothlauf, F. (2016). Explaining the internationalization of ibusiness firms. Journal of International Business Studies, 47(5), 513-534.

Burgelman, R. A. (1983). A process model of internal corporate venturing in the diversified major firm. Administrative science quarterly, 28(2), 223-244.

Burgelman, R. A., \& Välikangas, L. (2005). Managing internal corporate venturing cycles. MIT Sloan Management Review, 46(4), 26.

Burgers, J.H., Jansen, J.J.P., Van den Bosch, F.A.J., \& Volberda, H.W. (2009). Structural differentiation and corporate venturing: the moderating role of formal and informal integration mechanisms. Journal of Business Venturing, 24(3), 206-220.

Callaway, S. K. (2008). Global corporate ventures: a new trend of international corporate entrepreneurship. Multinational Business Review, 16(3), 1-22.

Campbell, A., Goold, M., \& Alexander, M. (1995). Corporate strategy: the quest for parenting advantage. Harvard business review, 73(2), 120-132.

Cassiman, B., \& Veugelers, R. (2006). In search of complementarity in innovation strategy: Internal R\&D and external knowledge acquisition. Management science, $52(1), 68-82$.

Chatterjee, S., Lubatkin, M. H., Schweiger, D. M., \& Weber, Y. (1992). Cultural differences and shareholder value in related mergers: Linking equity and human capital. Strategic management journal, 13(5), 319-334.

Christensen, C. M., Alton, R., Rising, C., \& Waldeck, A. (2011). The big idea: The new M\&A playbook. Harvard Business Review, 89(3), 48-57. 
Cohen, W. M., \& Levinthal, D. A. (1990). The implications of spillovers for R\&D investment and welfare: a new perspective. Administrative Science Quarterly, 35(1990), 128-152.

Covin, J. G., Garrett Jr, R. P., Gupta, J. P., Kuratko, D. F., \& Shepherd, D. A. (2016). The interdependence of planning and learning among internal corporate ventures. Entrepreneurship Theory and Practice.

Covin, J. G., Slevin, D. P., \& Covin, T. J. (1990). Content and performance of growthseeking strategies: A comparison of small firms in high-and low technology industries. Journal of Business Venturing, 5(6), 391-412.

Dess, G. G., Lumpkin, G. T., \& McGee, J. E. (1999). Linking corporate entrepreneurship to strategy, structure, and process: Suggested research directions. Entrepreneurship theory and practice, 23(3), 85-102.

Dess, G. G., \& Robinson, R. B. (1984). Measuring organizational performance in the absence of objective measures: the case of the privately-held firm and conglomerate business unit. Strategic management journal, 5(3), 265-273.

Eisenhardt, K. M., \& Martin, J. A. (2000). Dynamic capabilities: what are they?. Strategic management journal, 21(10/11), 1105-1121.

Fama, E. F., \& Jensen, M. C. (1983). Separation of ownership and control. The journal of law and Economics, 26(2), 301-325.

Fast, N. D. (1979). The future of industrial new venture departments. Industrial Marketing Management, 8(4), 264-273.

Garrett, R. P. (2010). Challenges of quantitative research on internal corporate venturing. International Journal of Entrepreneurial Venturing, 2(2), 129-143. 
Garrett, R. P., \& Covin, J. G. (2014). Parent Prospects, Resource Slack, and the Operations Independence of Internal Corporate Ventures. In Academy of Management Proceedings (Vol. 2014, No. 1, p. 16237). Briarcliff Manor, NY 10510: Academy of Management.

Garrett, R. P., \& Covin, J. G. (2015). Internal Corporate Venture Operations Independence and Performance: A Knowledge-Based Perspective. Entrepreneurship Theory and Practice, 39(4), 763-790.

Garrett, R. P., Covin, J. G., \& Slevin, D. P. (2009). Market responsiveness, top management risk taking, and the role of strategic learning as determinants of market pioneering. Journal of Business Research, 62(8), 782-788.

Garrett, R. P., \& Neubaum, D. O. (2013). Top management support and Initial strategic assets: A dependency model for internal corporate venture performance. Journal of Product Innovation Management, 30(5), 896-915.

Garson, G. D. (2013). Introductory guide to HLM with HLM 7 software. Hierarchical linear modeling: Guide and applications, 55-96.

Gompers, P., \& Lerner, J. (1998). Venture capital distributions: Short-run and long-run reactions. The Journal of Finance, 53(6), 2161-2183.

Gompers, P., \& Lerner, J. (2001). The venture capital revolution. Journal of economic perspectives, 15(2), 145-168.

Gupta, A. K., Smith, K. G., \& Shalley, C. E. (2006). The interplay between exploration and exploitation. Academy of management journal, 49(4), 693-706.

Hanan, M. (1976). Venturing corporations-think small to stay strong. Harvard Business Review, 54(3), 139-148. 
Helfat, C. E., Finkelstein, S., Mitchell, W., Peteraf, M., Singh, H., Teece, D., \& Winter, S. G. (2009). Dynamic capabilities: Understanding strategic change in organizations. John Wiley \& Sons.

Hill, S. A., \& Birkinshaw, J. (2014). Ambidexterity and survival in corporate venture units. Journal of management, 40(7), 1899-1931.

Hill, S. A., \& Georgoulas, S. (2016). 1. Internal corporate venturing: a review of (almost) five decades of literature. Handbook of Research on Corporate Entrepreneurship, 13.

Hill, S. A., Maula, M. V., Birkinshaw, J. M., \& Murray, G. C. (2009). Transferability of the venture capital model to the corporate context: Implications for the performance of corporate venture units. Strategic Entrepreneurship Journal, 3(1), $3-27$.

Hitt, M. A., Bierman, L., Uhlenbruck, K., \& Shimizu, K. (2006). The importance of resources in the internationalization of professional service firms: The good, the bad, and the ugly. Academy of Management Journal, 49(6), 1137-1157.

Hlavacek, J. D., \& Thompson, V. A. (1978). Bureaucracy and venture failures. Academy of Management Review, 3(2), 242-248.

Howell, D. C., Rogier, M., Yzerbyt, V., \& Bestgen, Y. (1998). Statistical methods in human sciences. New York: Wadsworth, 721.

Ireland, R. D., Hitt, M. A., \& Vaidyanath, D. (2002). Alliance management as a source of competitive advantage. Journal of management, 28(3), 413-446.

Ireland, R. D., \& Webb, J. W. (2007). Strategic entrepreneurship: Creating competitive advantage through streams of innovation. Business horizons, 50(1), 49-59. 
Jaworski, B. J., \& Kohli, A. K. (1993). Market orientation: antecedents and consequences. The Journal of marketing, 53-70.

Johnson, K. L. (2012). The role of structural and planning autonomy in the performance of internal corporate ventures. Journal of Small Business Management, 50(3), 469-497.

Kaplan, S. N., \& Minton, B. (2006). How has CEO turnover changed? Increasingly performance sensitive boards and increasingly uneasy CEOs (No. w12465). National Bureau of Economic Research.

Keil, T., McGrath, R. G., \& Tukiainen, T. (2009). Gems from the ashes: Capability creation and transformation in internal corporate venturing. Organization Science, 20(3), 601-620.

Kim, S. Y., Gonzales, N. A., Stroh, K., \& Wang, J. J. L. (2006). Parent-child cultural marginalization and depressive symptoms in Asian American family members. Journal of Community Psychology, 34(2), 167-182.

King, D. R., Covin, J. G., \& Hegarty, W. H. (2003). Complementary resources and the exploitation of technological innovations. Journal of Management, 29(4), 589606.

Klavans, R., Shanley, M., \& Evan, W. M. (1985). The Management of Internal Corporate Ventures-Entrepreneurship and Innovation. Columbia Journal of World Business, 20(2), 21-27.

Kogut, B., \& Singh, H. (1988). The effect of national culture on the choice of entry mode. Journal of international business studies, 19(3), 411-432. 
Kohli, A. K., \& Jaworski, B. J. (1990). Market orientation: the construct, research propositions, and managerial implications. The Journal of Marketing, 1-18.

Kuratko, D. F., \& Audretsch, D. B. (2013). Clarifying the domains of corporate entrepreneurship. International Entrepreneurship and Management Journal, 9(3), 323-335.

Kuratko, D. F., Covin, J. G., \& Garrett, R. P. (2009). Corporate venturing: Insights from actual performance. Business Horizons, 52(5), 459-467.

Kuratko, D. F., Covin, J. G., \& Hornsby, J. S. (2014a). Why implementing corporate innovation is so difficult. Business Horizons, 57(5), 647-655.

Kuratko, D. F., Hornsby, J. S., \& Covin, J. G. (2014b). Diagnosing a firm's internal environment for corporate entrepreneurship. Business Horizons, 57(1), 37-47.

Kuratko, D. F., Hornsby, J. S., \& Goldsby, M. G. (2012). Innovation acceleration: Transforming organizational thinking. (Upper Saddle River, Pearson/Prentice Hall): NJ.

Kuratko, D. F., Hornsby, J. S., \& Hayton, J. (2015). Corporate entrepreneurship: the innovative challenge for a new global economic reality. Small Business Economics, 45(2), 245-253.

Kuratko, D. F., Ireland, R. D., Covin, J. G., \& Hornsby, J. S. (2005). A Model of MiddleLevel Managers' Entrepreneurial Behavior. Entrepreneurship theory and practice, $29(6), 699-716$.

Lane, P. J., Koka, B. R., \& Pathak, S. (2006). The reification of absorptive capacity: A critical review and rejuvenation of the construct. Academy of management review, 31(4), 833-863. 
Lenox, M., \& King, A. (2004). Prospects for developing absorptive capacity through internal information provision. Strategic Management Journal, 25(4), 331-345.

Lichtenthaler, U. (2009). Absorptive capacity, environmental turbulence, and the complementarity of organizational learning processes. Academy of management journal, 52(4), 822-846.

Lowen, A., \& Pope, J. (2008). Survival analysis of international joint venture relationships. The Journal of Business and Economic Studies, 14(1), 62.

Luo, Y., \& Shenkar, O. (2011). Toward a perspective of cultural friction in international business. Journal of International Management, 17(1), 1-14.

MacMillan, I. C., \& George, R. (1985). Corporate venturing: Challenges for senior managers. Journal of Business Strategy, 5(3), 34-43.

March, J. G. (1991). Exploration and exploitation in organizational learning. Organization science, 2(1), 71-87.

McDougall, P. P. (1989). International versus domestic entrepreneurship: new venture strategic behavior and industry structure. Journal of Business Venturing, 4(6), $387-400$.

Mcgrath, R. G., Venkataraman, S., \& MacMillan, I. C. (1994). The advantage chain: Antecedents to rents from internal corporate ventures. Journal of business venturing, 9(5), 351-369.

Miles, M. P., \& Covin, J. G. (2002). Exploring the practice of corporate venturing: Some common forms and their organizational implications. Entrepreneurship theory and practice, 26(3), 21-40. 
Morris, M. H., Kuratko, D. F., \& Covin, J. G. (2010). Corporate entrepreneurship \& innovation. Cengage Learning.

Nell, P. C., \& Ambos, B. (2013). Parenting advantage in the MNC: An embeddedness perspective on the value added by headquarters. Strategic Management Journal, 34(9), 1086-1103.

Nippa, M., Pidun, U., \& Rubner, H. (2011). Corporate portfolio management: Appraising four decades of academic research. Academy of Management Perspectives, 25(4), 50-66.

Oviatt, B. M., \& McDougall, P. P. (1994). Toward a theory of international new ventures. Journal of international business studies, 25(1), 45-64.

Raudenbush, S. W., \& Bryk, A. S. (2002). Hierarchical linear models: Applications and data analysis methods (Vol. 1). Sage.

Riley, D., Kalafatis, S., \& Manoochehri, F. (2009). The impact of entrepreneurial orientation and managerial resources on corporate venture outcomes. International Journal of Entrepreneurship and Innovation Management, 9(3), 242-266.

Sathe, V. (1985). Culture and related corporate realities: Text, cases, and readings on organizational entry, establishment, and change. Richard D Irwin.

Schein, E. H. (1985). Organisational culture and leadership: A dynamic view. San Francisco.

Schollhammer, H. (1982). Internal corporate entrepreneurship. Encyclopedia of entrepreneurship, 209, 223. 
Semadeni, M., Withers, M.C., Certo S.T. (2014). The perils of endogeneity and instrumental variables in strategy research: Understanding through simulations. Strategic Management Journal, 35(7), 1070-1079.

Shenkar, O. (2001). Cultural distance revisited: Towards a more rigorous conceptualization and measurement of cultural differences. Journal of international business studies, 32(3), 519-535.

Shenkar, O. (2012). Cultural distance revisited: Towards a more rigorous conceptualization and measurement of cultural differences. Journal of International Business Studies, 43(1), 1-11.

Shrader, R. C., \& Simon, M. (1997). Corporate versus independent new ventures: Resource, strategy, and performance differences. Journal of Business Venturing, 12(1), 47-66.

Sherman, S. 1992. Are strategic alliances working? Fortune, September 21: 77-78.

Simon, M., Houghton, S. M., \& Gurney, J. (1999). Succeeding at internal corporate venturing: roles needed to balance autonomy and control. Journal of Applied Management Studies, 8(2), 145.

Song, M., Droge, C., Hanvanich, S., \& Calantone, R. (2005). Marketing and technology resource complementarity: An analysis of their interaction effect in two environmental contexts. Strategic management journal, 26(3), 259-276.

Sorrentino, M., \& Williams, M. L. (1995). Relatedness and corporate venturing: Does it really matter?. Journal of Business Venturing, 10(1), 59-73. 
Tallman, S. B., \& Shenkar, O. (1994). A managerial decision model of international cooperative venture formation. Journal of International Business Studies, 25(1), 91-113.

Tanriverdi, H., \& Venkatraman, N. (2005). Knowledge relatedness and the performance of multibusiness firms. Strategic management journal, 26(2), 97-119.

Thornhill, S., \& Amit, R. (2001). A dynamic perspective of internal fit in corporate venturing. Journal of business venturing, 16(1), 25-50.

Tseng, V., \& Fuligni, A. J. (2000). Parent-Adolescent language use and relationships among immigrant families with East Asian, Filipino, and Latin American backgrounds. Journal of Marriage and Family, 62(2), 465-476.

Von Hippel, E. (1977). The dominant role of the user in semiconductor and electronic subassembly process innovation. IEEE Transactions on Engineering Management, (2), 60-71.

Zahra, S. A., \& George, G. (2002). Absorptive capacity: A review, reconceptualization, and extension. Academy of management review, 27(2), 185-203.

Zahra, S. A., Ireland, R. D., \& Hitt, M. A. (2000). International expansion by new venture firms: International diversity, mode of market entry, technological learning, and performance. Academy of Management journal, 43(5), 925-950.

Zollo, M., Reuer, J. J., \& Singh, H. (2002). Interorganizational routines and performance in strategic alliances. Organization science, 13(6), 701-713. 


\section{Appendix}

Survey Items

Listing of the Internal Corporate Venturing Research Variables

Corporate Manager Information

Parent Corporation Information

Parent Corporation's Internal Corporate Venturing Experience

Venture Manager Information-Venture Manager

Venture Background Information

1. Venture physical location

2. Venture operational status

3. Venture development stage

4. Venture type

5. Venture age

6. Venture size

7. Venture Structural positioning

Cultural Distance- Corporate Manager

Cultural Distance- Venture Manager

Venture Performance - Corporate Manager

Venture Performance - Venture Manager

Turbulence Scales-both managers

Absorptive Capacity Scales-both managers

Learning Extensiveness

Venture Origin-Related Considerations

1. Top management support.

\section{Venture Autonomy}

1. Venture planning autonomy.

2. Venture operations autonomy.

3. Venture operations independence.

\section{Parent-Venture Similarity}

1. Parent-venture market similarity. 


\section{Operationalizations of the Internal Corporate Venturing Research Variables}

\section{Corporate Manager Information}

1. What is your position title?

2. How long have you been in your current position?

3. In what year did you join the corporation?

\section{Parent Corporation Information}

1. What is the name of your corporation?

2. What is the physical location of the corporation?

3. What is the approximate total sales revenue of your corporation for the latest full fiscal year? $\$$

4. Approximately what percentage of your corporation's total sales revenue is generated through sales made in your corporation's single largest industry? $\%$

5. Approximately how many persons does your corporation employ?

6. Is your corporation publicly or privately owned (circle one)? Public Private

\section{Parent Corporation's Internal Corporate Venturing Experience}

For purposes of the current research, an internal corporate venture is defined as an entrepreneurial initiative that originated within the corporate structure (or within an existing business of the corporation) and was intended from its inception as a new business for the corporation, where a new business is represented by the shaded cells in the following figure.

\begin{tabular}{|c|c|c|c|c|c|}
\hline & $\begin{array}{l}\text { Market Creation } \\
\text { (New to "World") }\end{array}$ & $\begin{array}{c}\text { New } \\
\text { Business }\end{array}$ & $\begin{array}{c}\text { New } \\
\text { Business }\end{array}$ & $\begin{array}{c}\text { New } \\
\text { Business }\end{array}$ & $\begin{array}{c}\text { New } \\
\text { Business }\end{array}$ \\
\hline \multirow{4}{*}{$\begin{array}{l}\text { Market Focus } \\
\text { of the Venture }\end{array}$} & $\begin{array}{l}\text { New Market for } \\
\text { the Corp. }\end{array}$ & $\begin{array}{l}\text { Major Market } \\
\text { Development }\end{array}$ & $\begin{array}{c}\text { New } \\
\text { Business }\end{array}$ & $\begin{array}{c}\text { New } \\
\text { Business }\end{array}$ & $\begin{array}{c}\text { New } \\
\text { Business }\end{array}$ \\
\hline & $\begin{array}{l}\text { Extension of } \\
\text { Current Market }\end{array}$ & $\begin{array}{l}\text { Minor Market } \\
\text { Development }\end{array}$ & $\begin{array}{c}\text { Minor Product- } \\
\text { Market } \\
\text { Development }\end{array}$ & $\begin{array}{c}\text { New } \\
\text { Business }\end{array}$ & $\begin{array}{c}\text { New } \\
\text { Business }\end{array}$ \\
\hline & $\begin{array}{l}\text { Current Market } \\
\text { of the Corp. }\end{array}$ & $\begin{array}{c}\text { Market } \\
\text { Penetration }\end{array}$ & $\begin{array}{l}\text { Minor Product } \\
\text { Development }\end{array}$ & $\begin{array}{l}\text { Major Product } \\
\text { Development }\end{array}$ & $\begin{array}{c}\text { New } \\
\text { Business }\end{array}$ \\
\hline & & $\begin{array}{l}\text { Current Product } \\
\text { of the Corp. }\end{array}$ & $\begin{array}{c}\text { Extension of } \\
\text { Current Product }\end{array}$ & $\begin{array}{l}\text { New Product for } \\
\text { the Corp. in } \\
\text { Current Industry }\end{array}$ & $\begin{array}{l}\text { New Product for } \\
\text { the Corp. in New } \\
\text { Industry (i.e., } \\
\text { Diversification) }\end{array}$ \\
\hline
\end{tabular}

Using the preceding definition of an internal corporate venture... 
1. Approximately how many distinct new internal corporate ventures has your corporation financially invested in (i.e., provided some level of start-up funding to) over the past 7 years regardless of whether these ventures are currently operating or were terminated somewhere along their development path?

2. How many internal ventures (7 years old or less) is your corporation currently pursuing in each of the following stages?

Early stage venture (start-up funding provided to venture, but no sales revenue yet generated)

Middle stage venture (generating some sales revenue, but no profit)

Established stage venture (generating some profit)

\section{Venture Manager Information- Venture Manager}

What is the name of your corporation?

What is your current position title?

How long have you been employed by your corporation?

In any corporation, and including the identified venture ...

1. With how many internal new ventures have you been personally and directly involved?

2. For how many internal new ventures have you been the principal manager?

\section{Venture Background Information}

Where is the venture physically located

Venture Operational Status - Whether the venture is currently operating or defunct.

Please indicate the operational status of the venture you're describing.

This venture is currently operating.

This venture is defunct - it has been terminated or otherwise expired.

\section{Venture Development Stage}

Please indicate the development stage of the venture you're describing.

Early Stage Venture - These ventures have received financial investment from the corporation or their sponsoring division, but are not yet generating any revenue. Alternatively, for a defunct venture in this stage, it never generated any revenue and was terminated.

Middle Stage Venture - These ventures are currently generating revenue, but are not yet profitable. Alternatively, for a defunct venture in this stage, it generated revenue but never generated any profit and was terminated. 
Established Stage Venture - These ventures are currently generating some profit (total estimated revenues exceed total estimated costs). Alternatively, for a defunct venture in this stage, it generated some profit but was, nonetheless, terminated.

If you are describing a middle or established stage venture, please indicate the venture's revenue for its latest year of operation. (For a defunct venture, please indicate the revenue it generated in the year of its expiry.) \$

Additionally, if you are describing an established stage venture, please indicate the venture's Return-on-Sales percentage (i.e., gross profit-to-sales ratio) for its latest year of operation. (For a defunct venture, please indicate the Return-on-Sales percentage it generated in the year of its expiry.) $\%$

\section{Venture Type}

Internal corporate ventures represent new businesses for the firm. Please place an " $X$ " in the shaded cell that best corresponds to the venture you're describing in this survey.

\begin{tabular}{|c|c|c|c|c|c|}
\hline \multirow{5}{*}{$\begin{array}{l}\text { Market Focus } \\
\text { of the Venture }\end{array}$} & $\begin{array}{l}\text { Market Creation } \\
\text { (New to "World") }\end{array}$ & $\begin{array}{c}\text { New } \\
\text { Business }\end{array}$ & $\begin{array}{c}\text { New } \\
\text { Business }\end{array}$ & $\begin{array}{c}\text { New } \\
\text { Business }\end{array}$ & $\begin{array}{c}\text { New } \\
\text { Business }\end{array}$ \\
\hline & $\begin{array}{l}\text { New Market for } \\
\text { the Corp. }\end{array}$ & $\begin{array}{l}\text { Major Market } \\
\text { Development }\end{array}$ & $\begin{array}{c}\text { New } \\
\text { Business }\end{array}$ & $\begin{array}{c}\text { New } \\
\text { Business }\end{array}$ & $\begin{array}{c}\text { New } \\
\text { Business }\end{array}$ \\
\hline & $\begin{array}{l}\text { Extension of } \\
\text { Current Market }\end{array}$ & $\begin{array}{l}\text { Minor Market } \\
\text { Development }\end{array}$ & $\begin{array}{l}\text { Minor Product- } \\
\text { Market } \\
\text { Development }\end{array}$ & $\begin{array}{c}\text { New } \\
\text { Business }\end{array}$ & $\begin{array}{c}\text { New } \\
\text { Business }\end{array}$ \\
\hline & $\begin{array}{l}\text { Current Market } \\
\text { of the Corp. }\end{array}$ & $\begin{array}{c}\text { Market } \\
\text { Penetration }\end{array}$ & $\begin{array}{l}\text { Minor Product } \\
\text { Development }\end{array}$ & $\begin{array}{l}\text { Major Product } \\
\text { Development }\end{array}$ & $\begin{array}{c}\text { New } \\
\text { Business }\end{array}$ \\
\hline & & $\begin{array}{l}\text { Current Product } \\
\text { of the Corp. }\end{array}$ & $\begin{array}{l}\text { Extension of } \\
\text { Current Product }\end{array}$ & $\begin{array}{l}\text { New Product for } \\
\text { the Corp. in } \\
\text { Current Industry }\end{array}$ & $\begin{array}{l}\text { New Product for } \\
\text { the Corp. in New } \\
\text { Industry (i.e., } \\
\text { Diversification) }\end{array}$ \\
\hline
\end{tabular}

Product Focus of the Venture

Venture Age

For a currently operating venture... please indicate the age of the venture you're describing, using the time at which initial start-up funding was provided to the venture as its founding date. years

For a defunct venture... please indicate the age of the venture at the time of its expiration, using the time at which initial start-up funding was provided to the venture as its founding date. years 


\section{Venture Size}

How many persons are currently assigned to the venture (or were at the time of a defunct venture's expiration) on a full-time basis? ...on a part-time basis?

Venture Structural Positioning - Where the venture is located in an organizational structure sense within the parent corporation.

Please indicate how the venture is (was) positioned within your corporate structure by circling the appropriate response to each question.

1. Does (did) the venture exist within a pre-existing, $\quad Y e s \quad$ No established business of the corporation?

2. Does (did) the venture exist within a dedicated new ventures unit? Yes No

\section{Cultural Distance Instrument- Venture Manager}

The following items relate to the BELIEFS AND ASSUMPTIONS that top management of the parent corporation and its corporate venture have about the IMPORTANCE of some business practices and procedures, and how things should be done for the success of a business. This instrument is divided into three columns in the first column the practice or procedure you are being asked to respond about is listed.

In the second column you are asked to indicate your level of agreement with: "This practice or procedure is one that management of my company believes or assumes is very important for the business to succeed." Please, circle for each item the most appropriate answer: a score of "1" means that you strongly DISAGREE with the statement, while a score of "7" means that you strongly AGREE.

In the third column you are asked to indicate your perceptions about the extent to which the importance of the following items is DIFFERENT for the top management group of your company VERSUS the top management group of the parent corporation. Please, circle for each item the most appropriate answer: a score of " 1 " means that the two top 
management groups are very SIMILAR, while a score of "7" means that they are very DIFFERENT.

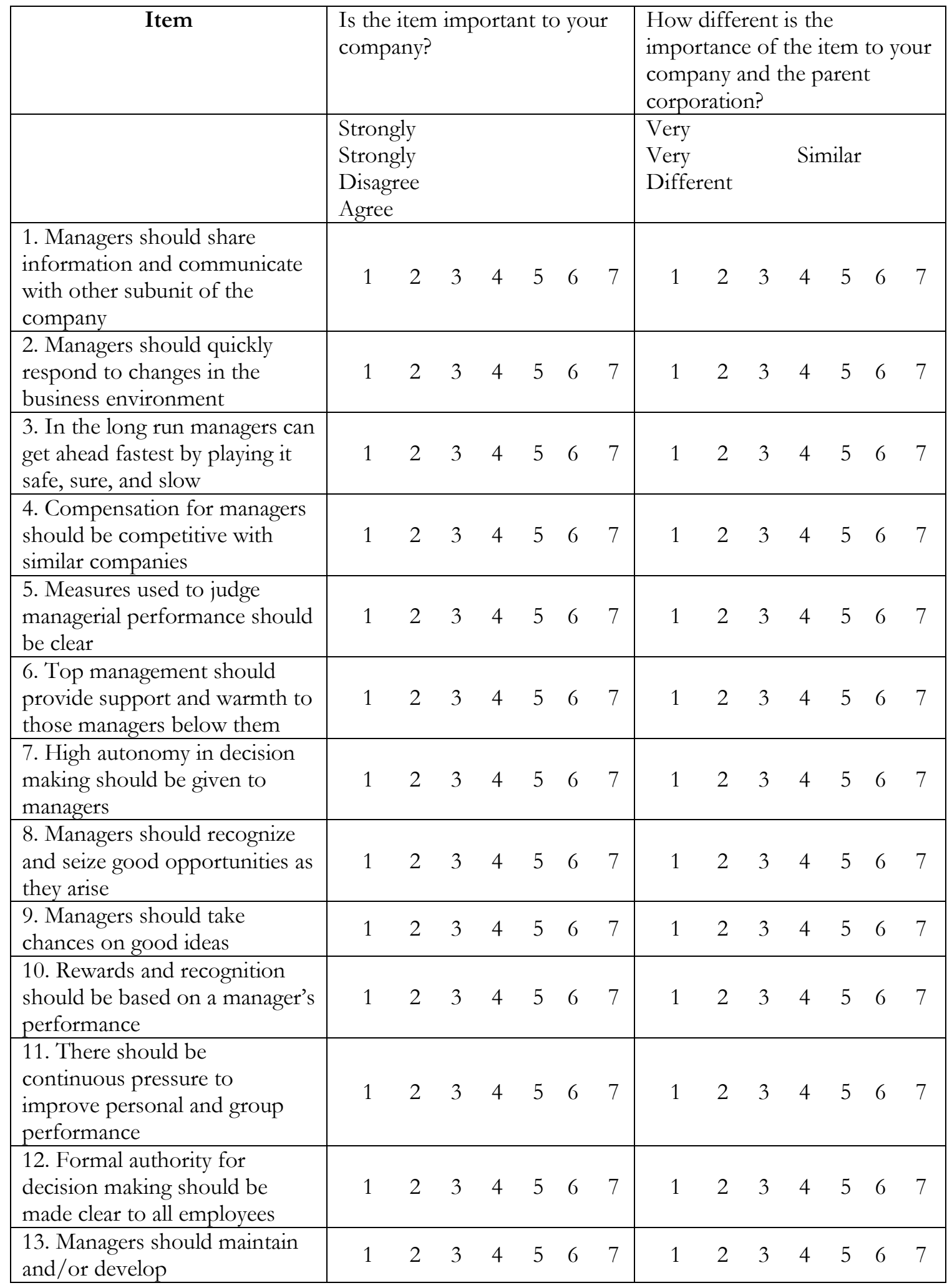




\begin{tabular}{|c|c|c|c|c|c|c|c|c|c|c|c|c|c|c|}
\hline $\begin{array}{l}\text { interrelationships with } \\
\text { managers of other departments }\end{array}$ & & & & & & & & & & & & & & \\
\hline $\begin{array}{l}\text { 14. Managers should be } \\
\text { encouraged to be innovative, } \\
\text { take independent actions, and } \\
\text { reasonable risks }\end{array}$ & 1 & 2 & 3 & 4 & 5 & 6 & 7 & 1 & 2 & 3 & 4 & 5 & 6 & 7 \\
\hline Item & $\begin{array}{l}\text { Is th } \\
\text { comp }\end{array}$ & & & & & & & $\begin{array}{l}\text { How } \\
\text { impo } \\
\text { comp } \\
\text { corpc }\end{array}$ & & $\mathrm{d}$ & & em & $\begin{array}{l}\text { to } y \\
t\end{array}$ & \\
\hline & $\begin{array}{l}\text { Stror } \\
\text { Stror } \\
\text { Disa } \\
\text { Agre }\end{array}$ & & & & & & & $\begin{array}{l}\text { Very } \\
\text { Very } \\
\text { Diffe }\end{array}$ & & & & tilar & & \\
\hline $\begin{array}{l}\text { 15. Managers should be } \\
\text { encouraged to air conflicts and } \\
\text { constructive criticism openly }\end{array}$ & 1 & 2 & 3 & 4 & 5 & 6 & 7 & 1 & 2 & 3 & 4 & 5 & 6 & 7 \\
\hline $\begin{array}{l}\text { 16. Formal rules and } \\
\text { procedures should be followed } \\
\text { in making and carrying out all } \\
\text { activities }\end{array}$ & 1 & 2 & 3 & 4 & 5 & 6 & 7 & 1 & 2 & 3 & 4 & 5 & 6 & 7 \\
\hline $\begin{array}{l}\text { 17. Managers should be } \\
\text { innovative rather than } \\
\text { conservative in decision } \\
\text { making }\end{array}$ & 1 & 2 & 3 & 4 & 5 & 6 & 7 & 1 & 2 & 3 & 4 & 5 & 6 & 7 \\
\hline $\begin{array}{l}\text { 18. Managerial promotions } \\
\text { should be highly associated } \\
\text { with excellence in performing } \\
\text { the job }\end{array}$ & 1 & 2 & 3 & 4 & 5 & 6 & 7 & 1 & 2 & 3 & 4 & 5 & 6 & 7 \\
\hline $\begin{array}{l}\text { 19. Managers should be free to } \\
\text { make independent decisions }\end{array}$ & 1 & 2 & 3 & 4 & 5 & 6 & 7 & 1 & 2 & 3 & 4 & 5 & 6 & 7 \\
\hline $\begin{array}{l}\text { 20. Calculated risks should be } \\
\text { taken at the right time }\end{array}$ & 1 & 2 & 3 & 4 & 5 & 6 & 7 & 1 & 2 & 3 & 4 & 5 & 6 & 7 \\
\hline $\begin{array}{l}\text { 21. Decision-making should be } \\
\text { timely }\end{array}$ & 1 & 2 & 3 & 4 & 5 & 6 & 7 & 1 & 2 & 3 & 4 & 5 & 6 & 7 \\
\hline $\begin{array}{l}\text { 22. Goals should be } \\
\text { venturesome }\end{array}$ & 1 & 2 & 3 & 4 & 5 & 6 & 7 & 1 & 2 & 3 & 4 & 5 & 6 & 7 \\
\hline $\begin{array}{l}\text { 23. Various subunit managers } \\
\text { should make efforts to } \\
\text { understand each other's } \\
\text { problems and difficulties }\end{array}$ & 1 & 2 & 3 & 4 & 5 & 6 & 7 & 1 & 2 & 3 & 4 & 5 & 6 & 7 \\
\hline $\begin{array}{l}\text { 24. Managers should be held } \\
\text { personally accountable for the } \\
\text { end results they produce }\end{array}$ & 1 & 2 & 3 & 4 & 5 & 6 & 7 & 1 & 2 & 3 & 4 & 5 & 6 & 7 \\
\hline $\begin{array}{l}\text { 25. To be effective, decision } \\
\text { makers should be very cautious }\end{array}$ & 1 & 2 & 3 & 4 & 5 & 6 & 7 & 1 & 2 & 3 & 4 & 5 & 6 & 7 \\
\hline $\begin{array}{l}\text { 26. Responsibility for decisions } \\
\text { should be clearly } \\
\text { communicated to all managers }\end{array}$ & 1 & 2 & 3 & 4 & 5 & 6 & 7 & 1 & 2 & 3 & 4 & 5 & 6 & 7 \\
\hline $\begin{array}{l}\text { 27. Managers should create and } \\
\text { maintain effective }\end{array}$ & 1 & 2 & 3 & 4 & 5 & 6 & 7 & 1 & 2 & 3 & 4 & 5 & 6 & 7 \\
\hline
\end{tabular}




\begin{tabular}{|c|c|c|c|c|c|c|c|c|c|c|c|c|c|c|}
\hline $\begin{array}{l}\text { communication and } \\
\text { cooperation with peers }\end{array}$ & & & & & & & & & & & & & & \\
\hline $\begin{array}{l}\text { 28. Managers should be } \\
\text { encouraged to expose conflicts } \\
\text { and to seek ways to resolve } \\
\text { them }\end{array}$ & 1 & 2 & 3 & 4 & 5 & 6 & 7 & 1 & 2 & 3 & 4 & 5 & 6 & 7 \\
\hline $\begin{array}{l}\text { 29. Promotion of managers } \\
\text { should be based on } \\
\text { competence as reflected by } \\
\text { their performance }\end{array}$ & 1 & 2 & 3 & 4 & 5 & 6 & 7 & 1 & 2 & 3 & 4 & 5 & 6 & 7 \\
\hline
\end{tabular}

\section{Cultural Distance Instrument- Corporate Manager}

The following items relate to the BELIEFS AND ASSUMPTIONS that top management of the parent corporation and its corporate venture have about the IMPORTANCE of some business practices and procedures, and how things should be done for the success of a business. This instrument is divided into three columns in the first column the practice or procedure you are being asked to respond about is listed.

In the second column you are asked to indicate your level of agreement with: "This practice or procedure is one that management of my company believes or assumes is very important for the business to succeed." Please, circle for each item the most appropriate answer: a score of "1" means that you strongly DISAGREE with the statement, while a score of "7" means that you strongly AGREE.

In the third column you are asked to indicate your perceptions about the extent to which the importance of the following items is DIFFERENT for the top management group of your company VERSUS the top management group of the venture. Please, circle for each item the most appropriate answer: a score of "1" means that the two top management groups are very SIMILAR, while a score of "7" means that they are very DIFFERENT. 


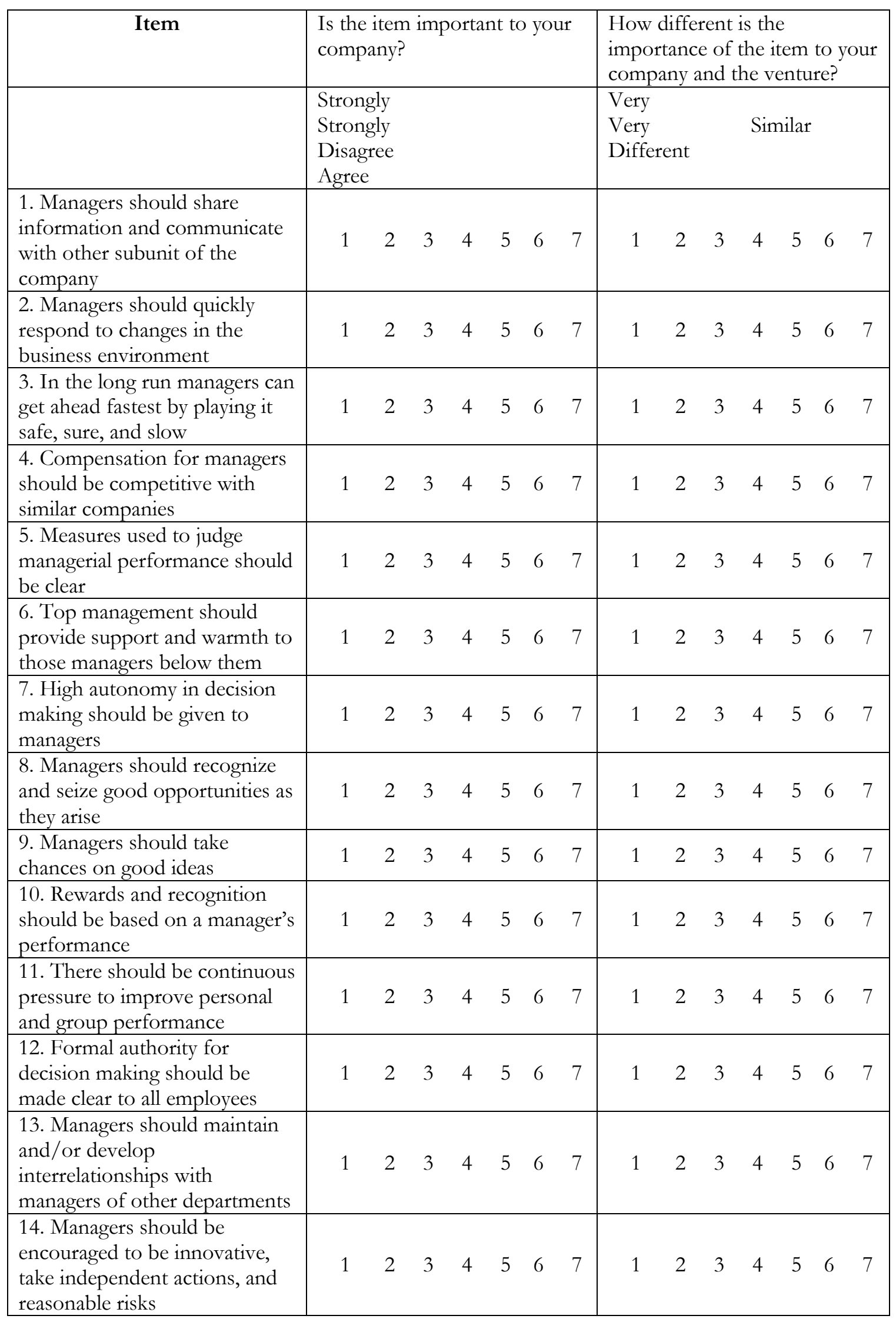




\begin{tabular}{|c|c|c|c|c|c|c|c|c|c|c|c|c|c|c|c|}
\hline \multirow[t]{2}{*}{ Item } & \multicolumn{7}{|c|}{$\begin{array}{l}\text { Is the item important to your } \\
\text { company? }\end{array}$} & \multicolumn{8}{|c|}{$\begin{array}{l}\text { How different is the } \\
\text { importance of the item to your } \\
\text { company and the venture? }\end{array}$} \\
\hline & $\begin{array}{l}\text { Stron } \\
\text { Stron } \\
\text { Disą } \\
\text { Agre }\end{array}$ & & & & & & & $\begin{array}{l}\text { Very } \\
\text { Very } \\
\text { Diff }\end{array}$ & & & $\mathrm{S}$ & nila & & & \\
\hline $\begin{array}{l}\text { 15. Managers should be } \\
\text { encouraged to air conflicts and } \\
\text { constructive criticism openly }\end{array}$ & 1 & 2 & 3 & 4 & 5 & 6 & 7 & 1 & 2 & 3 & 4 & 5 & 6 & & 7 \\
\hline $\begin{array}{l}\text { 16. Formal rules and } \\
\text { procedures should be followed } \\
\text { in making and carrying out all } \\
\text { activities }\end{array}$ & 1 & 2 & 3 & 4 & 5 & 6 & 7 & 1 & 2 & 3 & 4 & 5 & 6 & & 7 \\
\hline $\begin{array}{l}\text { 17. Managers should be } \\
\text { innovative rather than } \\
\text { conservative in decision } \\
\text { making }\end{array}$ & 1 & 2 & 3 & 4 & 5 & 6 & 7 & 1 & 2 & 3 & 4 & 5 & 6 & & 7 \\
\hline $\begin{array}{l}\text { 18. Managerial promotions } \\
\text { should be highly associated } \\
\text { with excellence in performing } \\
\text { the job }\end{array}$ & 1 & 2 & 3 & 4 & 5 & 6 & 7 & 1 & 2 & 3 & 4 & 5 & 6 & & 7 \\
\hline $\begin{array}{l}\text { 19. Managers should be free to } \\
\text { make independent decisions }\end{array}$ & 1 & 2 & 3 & 4 & 5 & 6 & 7 & 1 & 2 & 3 & 4 & 5 & 6 & & 7 \\
\hline $\begin{array}{l}\text { 20. Calculated risks should be } \\
\text { taken at the right time }\end{array}$ & 1 & 2 & 3 & 4 & 5 & 6 & 7 & 1 & 2 & 3 & 4 & 5 & 6 & & 7 \\
\hline $\begin{array}{l}\text { 21. Decision-making should be } \\
\text { timely }\end{array}$ & 1 & 2 & 3 & 4 & 5 & 6 & 7 & 1 & 2 & 3 & 4 & 5 & 6 & & 7 \\
\hline $\begin{array}{l}\text { 22. Goals should be } \\
\text { venturesome }\end{array}$ & 1 & 2 & 3 & 4 & 5 & 6 & 7 & 1 & 2 & 3 & 4 & 5 & 6 & & 7 \\
\hline $\begin{array}{l}\text { 23. Various subunit managers } \\
\text { should make efforts to } \\
\text { understand each other's } \\
\text { problems and difficulties }\end{array}$ & 1 & 2 & 3 & 4 & 5 & 6 & 7 & 1 & 2 & 3 & 4 & 5 & 6 & & 7 \\
\hline $\begin{array}{l}\text { 24. Managers should be held } \\
\text { personally accountable for the } \\
\text { end results they produce }\end{array}$ & 1 & 2 & 3 & 4 & 5 & 6 & 7 & 1 & 2 & 3 & 4 & 5 & 6 & & 7 \\
\hline $\begin{array}{l}\text { 25. To be effective, decision } \\
\text { makers should be very cautious }\end{array}$ & 1 & 2 & 3 & 4 & 5 & 6 & 7 & 1 & 2 & 3 & 4 & 5 & 6 & T & 7 \\
\hline $\begin{array}{l}\text { 26. Responsibility for decisions } \\
\text { should be clearly } \\
\text { communicated to all managers }\end{array}$ & 1 & 2 & 3 & 4 & 5 & 6 & 7 & 1 & 2 & 3 & 4 & 5 & 6 & t & 7 \\
\hline $\begin{array}{l}\text { 27. Managers should create and } \\
\text { maintain effective } \\
\text { communication and } \\
\text { cooperation with peers }\end{array}$ & 1 & 2 & 3 & 4 & 5 & 6 & 7 & 1 & 2 & 3 & 4 & 5 & 6 & 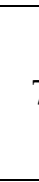 & 7 \\
\hline $\begin{array}{l}\text { 28. Managers should be } \\
\text { encouraged to expose conflicts } \\
\text { and to seek ways to resolve } \\
\text { them }\end{array}$ & 1 & 2 & 3 & 4 & 5 & 6 & 7 & 1 & 2 & 3 & 4 & 5 & 6 & & 7 \\
\hline
\end{tabular}




\begin{tabular}{|l|llllllll|llllllll|}
\hline $\begin{array}{l}\text { 29. Promotion of managers } \\
\text { should be based on } \\
\text { competence as reflected by } \\
\text { their performance }\end{array}$ & 1 & 2 & 3 & 4 & 5 & 6 & 7 & 1 & 2 & 3 & 4 & 5 & 6 & 7 \\
\hline
\end{tabular}

\section{Venture Performance - Corporate Manager}

Please respond to the statements below in reference to the venture in question. Because defunct ventures will have performed variously well prior to their expiration/termination, I am asking you to complete the following scale even if the venture in question is no longer operating. If the venture is defunct, please indicate how you would have evaluated the venture at the time of its expiration/termination. Indicate your level of agreement (by circling the appropriate number) with each statement based on the following scale:

$\begin{array}{ccccccc}\text { Strongly } & & \text { Slightly } & & \text { Slightly } & & \text { Strongly } \\ \text { Disagree } & \text { Disagree } & \text { Disagree } & \text { Neutral } & \text { Agree } & \text { Agree } & \text { Agree } \\ 1 & 2 & 3 & 4 & 5 & 6 & 7 \\ & & & & \text { Strongly } & & \end{array}$

Strongly

Agree

$$
\text { Disagree }
$$

1.) This venture generally meets (or met) the expectations of the parent corporation

2.) The parent corporation views (or viewed) this venture as being successful, overall

3.) The parent corporation believes (or believed) that $\quad \begin{array}{llllllll}1 & 2 & 3 & 4 & 5 & 6 & 7\end{array}$ this venture achieved its key milestones (i.e., events crucial to the venture's successful development) on schedule for each stage of its development

4.) The venture is performing (or performed) well in $\quad \begin{array}{llllllll}1 & 2 & 3 & 4 & 5 & 6 & 7\end{array}$ terms of the criteria (e.g., financial returns, market share, learning/ acquisition of new knowledge) the parent corporation considers (or considered) important to the venture's success.

\section{Venture Performance - Venture Manager}

Please respond to the statements below in reference to the venture in question. Because defunct ventures will have performed variously well prior to their expiration/termination, I am asking you to complete the following scale even if the venture in question is no longer operating. If the venture is defunct, please indicate how you would have evaluated the venture at the time of its expiration/termination. Indicate your level of agreement (by circling the appropriate number) with each statement based on the following scale: 


$\begin{array}{ccccccc}\text { Disagree } & \text { Disagree } & \text { Disagree } & \text { Neutral } & \text { Agree } & \text { Agree } & \text { Agree } \\ 1 & 2 & 3 & 4 & 5 & 6 & 7 \\ & & & & \text { Strongly } & & \end{array}$

Strongly

Disagree

Agree

1.) This venture generally meets (or met) the expectations of its managers

$\begin{array}{lllllll}1 & 2 & 3 & 4 & 5 & 6 & 7\end{array}$

2.) The venture managers view (or viewed) this venture as being successful, overall

3.) The venture managers believe (or believed) that $\quad \begin{array}{lllllllll}1 & 2 & 3 & 4 & 5 & 6 & 7\end{array}$ this venture achieved its key milestones (i.e., events crucial to the venture's successful development) on schedule for each stage of its development

4.) The venture is performing (or performed) well in $\begin{array}{llllllll}1 & 2 & 3 & 4 & 5 & 6 & 7\end{array}$ terms of the criteria (e.g., financial returns, market share, learning/ acquisition of new knowledge) the venture managers consider (or considered) important to the venture's success.

\section{Turbulence Scales}

The following items relate to the BELIEFS AND ASSUMPTIONS that top management within your corporation has about the turbulences and competition that your corporation faces. Please, circle for each item the most appropriate answer: a score of "1" means that you strongly disagree with the statement, while a score of "7" means that you strongly agree.

Strongly

\section{Strongly}

Agree

$$
\text { Disagree }
$$

\section{Market Turbulence}

1.) In our kind of business, customers' product preferences change quite a bit over time

2.) Our customers tend to look for new product all the time

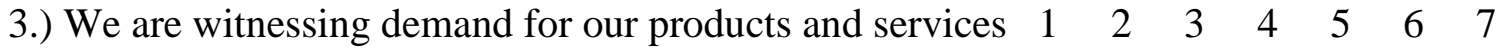
from customers who never bought them before

4.) New customers tend to have product-related needs that $\begin{array}{llllllll}1 & 2 & 3 & 4 & 5 & 6 & 7\end{array}$ 
are different from those of our existing customers

5.) We cater to many of the same customers that

we used to in the past

\section{Competitive Intensity}

1.) Competition in our industry is cutthroat

2.) There are many "promotion wars" in our industry

$\begin{array}{lllllll}1 & 2 & 3 & 4 & 5 & 6 & 7\end{array}$

3.) Anything that one competitor can offer, others can match readily

4.) Price competition is a hallmark of our industry $\quad \begin{array}{lllllll} & 1 & 2 & 3 & 4 & 5 & 6\end{array}$

5.) One hears of a new competitive move almost every day $\begin{array}{llllllll}1 & 2 & 3 & 4 & 5 & 6 & 7\end{array}$

6.) Our competitors are relatively weak

$\begin{array}{lllllll}1 & 2 & 3 & 4 & 5 & 6 & 7\end{array}$

Strongly

Strongly

Disagree

Agree

\section{Technological Turbulence}

1.) The technology in our industry is changing rapidly $\quad \begin{array}{lllllll}1 & 2 & 3 & 4 & 5 & 6 & 7\end{array}$

2.) Technological changes provide big opportunities in $\begin{array}{llllllll}1 & 2 & 3 & 4 & 5 & 6 & 7\end{array}$ our industry

3.) A large number of new product ideas have been made $\quad \begin{array}{lllllll}1 & 2 & 3 & 4 & 5 & 6 & 7\end{array}$ possible through technological breakthroughs in our industry

4.) Technological developments in our industry are $\quad \begin{array}{lllllll}1 & 2 & 3 & 4 & 5 & 6 & 7\end{array}$ rather minor 


\section{Absorptive Capacity Scales}

The following items relate to the learning activities that your company engages in. Please, circle for each item the most appropriate answer: a score of "1" means that you strongly disagree with the statement, while a score of "7" means that you strongly agree.

\section{Absorptive Capacity Scales}

Strongly

Agree

\section{Exploratory Learning-Recognize}

1.) We frequently scan the environment for new technologies

2.) We thoroughly observe technological trends

3.) We observe in detail external sources of new technologies

4.) We thoroughly collect industry information

5.) We have information on the state-of-the-art of external technologies

\section{$\underline{\text { Exploratory Learning-Assimilate }}$}

1.) We frequently acquire technologies from external sources

2.) We periodically organize special meetings with external partners to acquire new technologies

3.) Employees regularly approach external institutions to acquire technological knowledge

4.) We often transfer technological knowledge to our firm in response to technology acquisition opportunities

\section{Strongly}

Disagree

\section{$\begin{array}{lllllll}1 & 2 & 3 & 4 & 5 & 6 & 7\end{array}$}

$\begin{array}{lllllll}1 & 2 & 3 & 4 & 5 & 6 & 7\end{array}$

$\begin{array}{lllllll}1 & 2 & 3 & 4 & 5 & 6 & 7\end{array}$

$\begin{array}{lllllll}1 & 2 & 3 & 4 & 5 & 6 & 7\end{array}$

$\begin{array}{lllllll}1 & 2 & 3 & 4 & 5 & 6 & 7\end{array}$ $\begin{array}{lllllll}1 & 2 & 3 & 4 & 5 & 6 & 7\end{array}$

$\begin{array}{lllllll}1 & 2 & 3 & 4 & 5 & 6 & 7\end{array}$

$\begin{array}{lllllll}1 & 2 & 3 & 4 & 5 & 6 & 7\end{array}$

$\begin{array}{lllllll}1 & 2 & 3 & 4 & 5 & 6 & 7\end{array}$

\section{$\underline{\text { Transformative Learning-Maintain }}$}

1.) We thoroughly maintain relevant knowledge over time $\begin{array}{lllllll}1 & 2 & 3 & 4 & 5 & 6 & 7\end{array}$ 
2.) Employees store technological knowledge for future reference

3.) We communicate relevant knowledge across the units $\quad \begin{array}{lllllll}1 & 2 & 3 & 4 & 5 & 6 & 7\end{array}$ of our firm

4.) Knowledge management is functioning well in our company

$\begin{array}{lllllll}1 & 2 & 3 & 4 & 5 & 6 & 7\end{array}$

Strongly

Strongly

Disagree

Agree

\section{$\underline{\text { Transformative Learning-Reactivate }}$}

1.) When recognizing a business opportunity, we can $\quad \begin{array}{llllllll}1 & 2 & 3 & 4 & 5 & 6 & 7\end{array}$ quickly rely on our existing knowledge

2.) We are proficient in reactivating existing knowledge for new uses

3.) We quickly analyze and interpret changing market demands for our technologies

$\begin{array}{lllllll}1 & 2 & 3 & 4 & 5 & 6 & 7\end{array}$

4.) New opportunities to serve our customers with existing $\quad \begin{array}{lllllll}1 & 2 & 3 & 4 & 5 & 6 & 7\end{array}$ technologies are quickly understood

\section{$\underline{\text { Exploitative Learning-Transmute }}$}

1.) We are proficient in transforming technological $\quad \begin{array}{lllllll}1 & 2 & 3 & 4 & 5 & 6 & 7\end{array}$ knowledge into new products

2.) We regularly match new technologies with ideas $\quad \begin{array}{lllllll}1 & 2 & 3 & 4 & 5 & 6 & 7\end{array}$ for new products

3.) We quickly recognize the usefulness of new technological knowledge for existing knowledge

4.) Our employees are capable of sharing their expertise $\quad \begin{array}{lllllll}1 & 2 & 3 & 4 & 5 & 6 & 7\end{array}$ to develop new products

\section{Exploitative Learning-Apply}


1.) We regularly apply technologies in new products

2.) We constantly consider how to better exploit technologies

3.) We easily implement technologies in new products

4.) It is well known who can best exploit new technologies inside our firm $\begin{array}{lllllll}1 & 2 & 3 & 4 & 5 & 6 & 7\end{array}$

$\begin{array}{lllllll}1 & 2 & 3 & 4 & 5 & 6 & 7\end{array}$

$\begin{array}{lllllll}1 & 2 & 3 & 4 & 5 & 6 & 7\end{array}$

$\begin{array}{lllllll}1 & 2 & 3 & 4 & 5 & 6 & 7\end{array}$

\section{Learning Extensiveness}

Knowledge Acquisition Extensiveness - The extent to which management's knowledge pertaining to various aspects of operations has increased over the course of the venture's development.

Please indicate on the following scale (by circling the appropriate number) the extent to which management's knowledge in the following areas increased over the course of the venture's development? For a venture that is no longer operating, consider knowledge gains from the time of the venture's inception to its expiration.

What we know about about

\section{this matter has \\ not increased \\ increased}

since the venture was

was initially approved

$1 \quad 2$
What we know about

this matter has

moderately increased

since the venture was

initially approved

4

5

What we know

this matter has

dramatically

since the venture

initially approved

$6 \quad 7$

Knowledge pertaining to...

1. the determinants of demand in our targeted market.

$\begin{array}{lllllll}1 & 2 & 3 & 4 & 5 & 6 & 7\end{array}$

2. important attributes of product and/or service offerings.

$\begin{array}{lllllll}1 & 2 & 3 & 4 & 5 & 6 & 7\end{array}$

3. competitive dynamics in our industry.

$\begin{array}{lllllll}1 & 2 & 3 & 4 & 5 & 6 & 7\end{array}$

4. important qualities of a viable competitive strategy.

$\begin{array}{lllllll}1 & 2 & 3 & 4 & 5 & 6 & 7\end{array}$

5. important characteristics of the internal operations (i.e., structure and $\begin{array}{lllllll}1 & 2 & 3 & 4 & 5 & 6 & 7\end{array}$ process considerations).

6. characteristics of an effective business model.

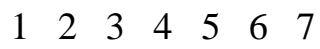

7. the types of assets/resources needed to excel competitively.

8. how to best structure relationships between a venture

$\begin{array}{lllllll}1 & 2 & 3 & 4 & 5 & 6 & 7\end{array}$ and a parent corporation.

9. how to communicate effectively with others.

10. new ideas about how to perform my job.

11. new skills to improve the way I perform my job.

$\begin{array}{lllllll}1 & 2 & 3 & 4 & 5 & 6 & 7\end{array}$

$\begin{array}{lllllll}1 & 2 & 3 & 4 & 5 & 6 & 7\end{array}$

$\begin{array}{lllllll}1 & 2 & 3 & 4 & 5 & 6 & 7\end{array}$

$\begin{array}{lllllll}1 & 2 & 3 & 4 & 5 & 6 & 7\end{array}$

\section{Venture Origin-Related Considerations}

IMPORTANT NOTE TO SURVEY RESPONDENT: When a survey item mentions a verb in both the present and past tense -for example, the next survey item reads "The venture has 
(had) the strong support of the parent corporation's senior-level management." - the past tense wording of the item is meant to apply solely to ventures that are defunct.

Top Management Support - The extent to which the parent company's senior-level management is supportive of the venture.

Please indicate your level of agreement (by circling the appropriate number) with each of the following statements based on the following scale:

\begin{tabular}{ccccccc} 
Strongly & \multicolumn{3}{c}{ Slightly } & Slightly & & Strongly \\
Disagree & Disagree & Disagree & Neutral & Agree & Agree & Agree \\
1 & 2 & 3 & 4 & 5 & 6 & 7
\end{tabular}

1. The venture has (had) the strong support of the parent corporation's senior-level management.

2. The venture has (had) a committed champion/advocate within the parent corporation's top management ranks.

3. The parent corporation's senior-level management has (had) openly expressed verbal commitments to the venture's success.

4. Actions and resource allocations of the parent company's

$\begin{array}{lllllll}1 & 2 & 3 & 4 & 5 & 6 & 7\end{array}$

$\begin{array}{lllllll}1 & 2 & 3 & 4 & 5 & 6 & 7\end{array}$ senior-level management are (were) clearly supportive of the venture.

\section{Venture Autonomy}

Venture Planning Autonomy - The extent to which the venture's management team (vs. corporate parent management) is responsible for establishing goals, timetables, event milestones, and strategy for the venture.

Please indicate (by circling the appropriate number) your response to the following question based on the following scale.

responsibility

The sole responsibility of a higher level(s) of authority of venture-level management of a higher level(s) of authority venture-level within the corporation
1
2

Equally the responsibility

The sole

Who is (was) responsible for each of the following venture activities and decision areas?

1. Setting of the venture's goals.

2. Establishment of a timetable (if applicable) for the achievement of the venture's goals.

within the corporation and venture-level management

3. Choice of formal criteria used to measure the venture's performance. $\begin{array}{lllllll}1 & 2 & 3 & 4 & 5 & 6 & 7\end{array}$

4. Identification of event milestones (if any) used to assess the venture's progress.

5. Formulation of the venture's business strategy.

6. Decision to change (if necessary) the venture's business strategy. $\quad \begin{array}{lllllll}1 & 2 & 3 & 4 & 5 & 6 & 7\end{array}$

Venture Operations Autonomy - The extent to which the venture's management team (vs. corporate parent management) is responsible for the design of the venture's internal operations. 
Please indicate (by circling the appropriate number) your response to the following question based on the following scale.

responsibility

The sole responsibility

management

of a higher level(s) of authority

venture-level within the corporation

$$
12
$$

Equally the responsibility

of a higher level(s) of authority

within the corporation and

venture-level management

$3 \quad 4 \quad 5$
The sole

of venture-level

$6 \quad 7$

Who is (was) responsible for each of the following venture activities and decision areas?

1. The venture's operating and decision policies.

2. The venture's administrative/organizational structure.

3. The venture's communications and reporting relationships.

4. The venture's workflow and operating processes.

5. The venture's standard operating procedures.

6. The venture's overall business model. $\begin{array}{llllllll}1 & 2 & 3 & 4 & 5 & 6 & 7\end{array}$

$\begin{array}{lllllll}1 & 2 & 3 & 4 & 5 & 6 & 7\end{array}$

$\begin{array}{lllllll}1 & 2 & 3 & 4 & 5 & 6 & 7\end{array}$

$\begin{array}{lllllll}1 & 2 & 3 & 4 & 5 & 6 & 7\end{array}$

$\begin{array}{lllllll}1 & 2 & 3 & 4 & 5 & 6 & 7\end{array}$

$\begin{array}{lllllll}1 & 2 & 3 & 4 & 5 & 6 & 7\end{array}$

Venture Operations Independence - The extent to which the venture's operations are linked to those of other businesses of the corporation.

Please indicate your level of agreement (by circling the appropriate number) with each of the following statements based on the following scale:

\begin{tabular}{ccccccc} 
Strongly & \multicolumn{3}{c}{ Slightly } & Slightly & Strongly \\
Disagree & Disagree & Disagree & Neutral & Agree & Agree & Agree \\
1 & 2 & 3 & 4 & 5 & 6 & 7
\end{tabular}

1. The venture operates (operated) as a self-contained business unit, $\quad \begin{array}{lllllll}1 & 2 & 3 & 4 & 5 & 6 & 7\end{array}$ with few or weak structural or process linkages with other businesses of the corporation.

2. The venture's operations are (were) not significantly constrained $\quad \begin{array}{lllllll}1 & 2 & 3 & 4 & 5 & 6 & 7\end{array}$ or dictated by formal structural or process linkages with other businesses of the corporation.

3. The venture operates (operated) in an independent manner vis-à-vis other businesses of the corporation.

\section{Parent-Venture Similarity}

Parent-Venture Market Similarity - The extent to which the venture is similar to other businesses of the corporation in terms of markets served.

Please indicate your level of agreement (by circling the appropriate number) with each of the following statements based on the following scale:

\begin{tabular}{|c|c|c|c|c|c|c|}
\hline Strongly & & Slightly & & Slightly & & Strongly \\
\hline Disagree & Disagree & Disagree & Neutral & Agree & Agree & Agree \\
\hline 1 & 2 & 3 & 4 & 5 & 6 & 7 \\
\hline
\end{tabular}

1. The venture's actual or proposed customer market is (was) $\quad \begin{array}{lllllll}1 & 2 & 3 & 4 & 5 & 6 & 7\end{array}$ 
already served by another business of the corporation.

2. The venture's actual or proposed customer market is (was)

$\begin{array}{lllllll}1 & 2 & 3 & 4 & 5 & 6 & 7\end{array}$ highly similar or strongly related to one already served by another business of the corporation.

3. The venture's actual or proposed customer market is (was) well known to the corporation based on past sales from other businesses of the corporation. 


\title{
CURRICULUM VITAE
}

\author{
Tommie Welcher
}

\section{Dissertation Accepted}

October 15,2020

\section{Dissertation Committee}

\author{
Dr. Robert P. Garrett (Chair) \\ Dr. James O. Fiet \\ Dr. David A. Dubofsky \\ Dr. Simon C. Parker
}

\section{PUBLICATIONS}

- Welcher, T. R. (2019). A New Way to Look at an Old Problem: International Joint Venture Partner Selection via Constrained Systematic Search. Business Horizons, 62 (2), 199-205.

- Garrett, R.P., \& Welcher, T. R. (2018). Corporate Entrepreneurship as a Survival Routine. The Challenges of Corporate Entrepreneurship in the Disruptive Age (Advances in the Study of Entrepreneurship, Innovation, and Economic Growth, Volume 28). Emerald Publishing Limited, 111-122.

\section{ARTICLES IN PROGRESS}

- Welcher, T. R. \& Garrett, R. P. Venturing in the Social Age: The Impact of Social Media on Corporate Venturing Decisions. Preparing for submission to Journal of World Business.

- Garrett, R.P., Welcher, T. R., Aguirre, M. A. The Constrained SME: The Impact of Government Regulations on SME Corporate Entrepreneurship. Preparing for submission to Entrepreneurship Theory and Practice.

\section{CLASSES TAUGHT}

- ENTR 350 Introduction to Innovation and Creativity

- Student Evaluations Fall 2017: 4.22/5

- Student Evaluations Spring 2018: 4.86/5 
- ENTR 401 New Venture Creation

- Student Evaluations Spring 2019: 4.32/5

\section{EDUCATION}

University of Louisville, Louisville, KY

PhD, Entrepreneurship August 2015-December 2020

MBA, May 2015

- Graduated with distinction

- GPA: 3.79

B.S. in Business Administration; Accounting and Equine Business, December 2009

- Honors: Dean's List (6 semesters) and Honors Program

- GPA: 3.341

- Completed 150 hours

\section{HONORS}

- Trustees Scholarship August 2005

- Graduate Assistantship August 2013

- Graduate Fellowship August 2015

\section{EMPLOYMENT}

University of Louisville, Louisville, KY

September 2013-Present

Graduate Assistant

- Taught Creativity and Innovation Course two semesters

- Tutored students in accounting, finance

- Assisted with research projects

- Proctored exams

- Entrepreneurship

\section{RESEARCH INTERESTS}

- Corporate entrepreneurship

- Cultural Distance

- International joint ventures

- Partner Selection

\section{PROFESSIONAL MEMBERSHIPS}

- Academy of Management 


\section{COURSEWORK}

\section{THEORETICAL COURSES}

- Foundations of Entrepreneurship

James Fiet

- Contemporary Entrepreneurship

- Organizational Behavior in Entrepreneurial Firms

- Philosophy of Science

- Economic Theory of a Firm

- Psychological Foundations of Entrepreneurship Research

- Quantitative Approach to Entrepreneurship Research

- Economic Foundations of Entrepreneurship Research

- Sociological Foundations of Entrepreneurship Research

- Strategic Perspectives of Entrepreneurship Research

- Venture Capital \& Entrepreneurial Finance

- Finance Theories

- Discovery \& Opportunity Theories

- Family Business Research

- Social Entrepreneurship Research

Scott Shane

Bruce Kemelgor

Robert Garrett

Yong Chao

Dean Shepherd

Per Davidsson

Simon Parker

Howard Aldrich

Robert Garrett

James Fiet

David Dubofsky

James Fiet

Jim Chrisman

Tom Lumpkin

\section{METHODOLOGICAL COURSES}

- Dyadic Data Analysis (DATIC)

- Structural Equation Modeling

David Kenny/Randi Garcia

- Research Design/Methods

- New Product Strategy/Marketing

- Multivariate Statistics

- Advanced Statistics

- Independent Study, Non Parametric Statistics

- Experimental Design

Jill Adelson

Manju Ahuja

Robert Carter

Namok Choi

Cara Cashon

James Fiet

Manju Ahuja

\section{PEDAGOGICAL DEVELOPMENET}

- Graduate Teaching Academy

Michelle Rodems 